\title{
LUZ E NEVOEIROS: \\ A IMPRENSA PERIÓDICA MINEIRA NO PERÍODO REGENCIAL (1831-1840)
}

Wlamir José Silva ${ }^{1 ; 2}$

\section{Resumo}

Este artigo trata da imprensa periódica da província de Minas Gerais no período regencial (1831-1840), em especial da perspectiva da representação política em sentido amplo, das relações entre Estado e sociedade, representado e representante, sociedade civil e sociedade política, governantes e governados e da participação do povo no seio do "Protótipo dos Toucinheiros".

\section{Palavras-chave}

Imprensa - província de Minas Gerais - Brasil Império - período regencial - sistema representativo.

\section{LIGHT AND FOG: \\ THE PERIODIC PRESS FROM MINAS GERAIS IN THE REGENCY PERIOD (1831-1840)}

\section{Abstract}

This article deals with the periodical press of the province of Minas Gerais during the Regency period (1831-1840) especially from the perspective of political representation in a broad sense, relations between State and society, represented and representative, civil society and political society, governors and governed and the participation of the people in the "Prototype of the Toucinheiros" (bacon sellers).

\section{Keywords}

Press - province of Minas Gerais - Brazil Empire - regency period - representative system.

\footnotetext{
${ }^{1}$ Universidade Federal de São João del-Rei - São João del-Rei - MG - Brasil

${ }^{2}$ Doutor em História Social pela Universidade Federal do Rio de Janeiro e professor associado da Universidade Federal de São João del-Rei. E-mail: wlamir-silva@uol.com.br
} 


\section{Imprensa e povo}

O papel da imprensa nos Oitocentos diz algo sobre a gênese do Estado nacional brasileiro quanto às relações entre sociedade e Estado. A medida pela qual a imprensa teria influenciado o comportamento da sociedade balizaria o grau de politização nos termos da modernidade. Grosso modo, opõese tal influência a certa impermeabilidade daquela sociedade pelo que era tratado pela imprensa. Impermeabilidade que se inscreve numa abordagem pessimista da representação política no Império, em virtude da presença da escravidão, do caráter agrário, das fraudes e violências eleitorais, do Poder Moderador e da vitaliciedade do Senado ${ }^{3}$. Ao fim e ao cabo, da afirmação mais ou menos categórica da inexistência de povo, de um povo-nação, povo-cidadão moderno ${ }^{4}$.

Tal pessimismo interpretativo e heurístico, que se insinua como interdição investigativa, tem sido questionado até pela relativização das diferenças dos processos representativos europeus e estadunidense nas primeiras décadas dos Oitocentos ${ }^{5}$. É ainda mais "pirrônico"6 no que tange ao período regencial do Império brasileiro (1831-1840), no qual estiveram ausentes o Poder Moderador e a pessoa do imperador, e evidenciou-se a emergência de projetos políticos num efervescente "laboratório da nação". Neste, houve embates quanto a desenhos institucionais, sociais e relativos à extensão e formas da participação popular, assim como o aprofundamento da recém-criada esfera pública e da disputa pela opinião a ela pertinente ${ }^{8}$, o que envolvia aspectos institucionais, embora em boa parte definidos na Carta de 1824, mas também algo mais abrangente nas mobilizações eleitorais, nas praças e ruas e mesmo no alvitre dos motins e movimentos armados que amiúde se originaram ou se serviram das contendas propriamente políticas.

O embate dos grupos políticos delineados - exaltados, moderados e caramurus - pela hegemonia na conflituosa década se relacionava com a definição da representação política não num plano apenas formal, mas num sentido mais amplo. Mediam-se as relações entre representado e representante, sociedade civil e sociedade política, dirigentes e dirigidos, governantes e governados ${ }^{9}$. Admitida esta premissa, a imprensa adquire uma dimensão ímpar como fonte e ingrediente do processo, de sua substância e inconsistências pela evidência empírica do seu crescimento e das correlações com as conjunturas políticas no período.

Noutra dimensão historiográfica, destaca-se o fato de o Brasil oitocentista ter, a par dos Estados Unidos, enfrentado o desafio da representação política de moldes liberais em território de dimensões continentais. Tal fato exige um esforço investigativo que contemple as diversidades e as interações regionais, o que vale para a constituição do sistema representativo e para a imprensa. A fixação das ideias e dos debates pela escritura e a duração que ela proporcionou permitiam ao conjunto de cidadãos "entrar e combater, tendo por juiz a Nação inteira" ${ }^{0}$. Meios que possibilitaram a criação de redes de

\footnotetext{
${ }^{3}$ DOLHNIKOFF, Miriam et al. Representação política no Império: crítica à ideia do falseamento institucional. In: LAVALLE, Adrian Gurza (org.). O horizonte da política. São Paulo: Editora Unesp; CEM, 2012. p. 97-141.

${ }^{4}$ Em síntese, cf. PEREIRA, Luísa Pereira. O povo na história do Brasil: linguagem e historicidade no debate político (1750-1870). São Paulo: Paco, 2016. p. 21-31.

${ }^{5}$ Quanto às semelhanças do caráter elitista da representação ver DOLHNIKOFF, Miriam. Império e governo representativo: uma releitura. Caderno CRH, Salvador, vol. 21, n. 52, p. 13-23, p. 14-15, jan./abr. 2008, e MANIN, Bernard. Los princípios del gobierno representativo. Madri: Alianza Editorial, 2006.

${ }^{6}$ LAMOUNIER, Bolívar. Da Independência a Lula: dois séculos de política brasileira. São Paulo: Augurium, 2005. p. 15-16.

${ }^{7}$ BASILE, Marcello. O laboratório da nação: a era regencial (1831-1840). In: GRINBERG, Keila \& SALLES, Ricardo (org.). $O$ Brasil imperial, vol. II: 1831-1870. Rio de Janeiro: Civilização Brasileira, 2009.

${ }^{8}$ SLEMIAN, Andréa. Sob o império das leis. Constituição e unidade nacional na formação do Brasil (1822-1834). São Paulo: Hucitec / Fapesp, 2009, e MOREL, Marco. As transformações dos espaços públicos: imprensa, atores políticos e sociabilidades na cidade imperial (1820-1840). São Paulo: Hucitec, 2005.

${ }^{9}$ COSPITO, Giuseppe. Representados-representantes. In: LIGUORI, Guido; VOZA, Pasquale (org.). Dicionário gramsciano (19261937). São Paulo: Boitempo, 2017. p. 692-695. GRAMSCI, Antônio. Cadernos do cárcere, vol. 3. Rio de Janeiro: Civilização Brasileira, 2002. p. 301-302.

${ }^{10}$ Quaes são os bens e os males que podem resultar da liberdade da Imprensa; e qual he a influencia que eles podem ter no momento em que os Representantes da Nação Portuguesa se vão congregar? In: CARVALHO, José Murilo; BASTOS, Lúcia; BASILE, Marcello (org.). Guerra literária: panfletos da Independência (1820-1823), vol. 2. Belo Horizonte: UFMG, [1821] 2014. p. 205206.
} 
comunicação que ampliavam o alcance geográfico, social e, ainda, o julgamento crítico do cidadãoleitor e a amplificação dos espaços públicos ${ }^{11}$.

A imprensa e a circulação de ideias, conceitos e perspectivas de representação política se espraiando por regiões e províncias moldam em alguma medida o "modo abstrato ou anônimo"12 de participação política da representação e nação modernas. Como disse Sieyès: "milhões de homens não se reúnem em uma praça pública"13. O cidadão moderno é uma abstração ${ }^{14}$, membro abstrato da nação, como observa Pierre Rosanvallon ${ }^{15}$, na consciência política da sociedade civil em formação, elevada, como observa Marx, à abstração de si mesma. Ao dirigir-se a um conjunto de cidadãos - abstraídos os pertencimentos locais, ainda balizados pelas sobrevivências corporativas do Antigo Regime em sua forma colonial -, a imprensa intenta inserir os indivíduos como partes da "abstração do 'Estado' somente político". Na lógica liberal, o "mérito dos franceses (...) de terem firmado essa realidade abstrata (...) em uma oposição necessária (...) da reencontrada disposição política”, o horizonte do indivíduo é abstratamente traduzido como cidadão, como "todos" e, à maneira liberal, como "singular"16.

\section{Minas na praça pública}

No tempo das regências, o Brasil vivia mais na praça pública do que no lar doméstico - a expressão vem, sugestivamente, das recordações do fazendeiro e político mineiro Francisco Rezende. A opção monárquica e a traumática abdicação, não fortuitamente, envolveram viagens de d. Pedro a Minas, província contígua ao pretendido centro de poder. O deputado "mineiro" Evaristo da Veiga, que nunca fora a Minas que lhe servia votos, daria o tom do liberalismo moderado e via entre os mineiros o apego ao regime representativo pelo "espírito constitucional (...) derramado em todas as classes da sociedade (...) [em contraste com a] obscura Aristocracia. (...) Empregados quase todos no trabalho, na cultura das terras ou na mineração"17. Também viria da montanhosa província a voz de Bernardo Pereira de Vasconcelos, entrevada, mas poderosa, da virada regressista. Em que pese a efervescência da Corte, a Babilônia, na expressão do também mineiro Teófilo Otoni, nos interiores mais mansos que a capital ou que as irmãs do Norte, cavara a silenciosa e tenaz toupeira da história, na Independência, na Revolução do Sete de Abril e na antessala da viragem conservadora ${ }^{18}$.

Se em abril de 1822 o príncipe chegara à Corte como o "novo herói de Minas"19 e protagonizara em meses a Independência, em abril de 1831 saíra da província sob as graves suspeitas quanto ao seu liberalismo e fora recebido na Corte num turbilhão que o levaria à abdicação em menos de um mês. A Revolução do Sete de Abril e a abdicação inauguravam a década marcada pelo vazio monárquico que ensejava riscos e oportunidades: os riscos da desordem que haviam animado a opção monárquica em torno do enigmático príncipe português e as oportunidades de fazer valer a sociedade como demiurgo

\footnotetext{
${ }^{11}$ MOREL, Marco. As transformações dos espaços públicos..., Op. Cit., p. 205-206.

${ }^{12}$ MANIN, Bernard. Los princípios del gobierno representativo..., Op. Cit., 2006. p. 169-170.

${ }^{13}$ Apud SIERRA, María; PEÑA, Maria Antonia; ZURITA, Rafael. Elegidos y elegibles: la representación parlamentaria en la cultura del liberalismo. Madri: Marcial Pons, 2010. p. 53.

${ }^{14}$ GUERRA, François-Xavier. El soberano y su reino: reflexiones sobre la génesis del ciudadano en América Latina. In: SABATO, Hilda. (coord.). Ciudadanía política y formación de las naciones: perspectivas históricas de América Latina. México, D.F.: Fondo de Cultura Económica, 1999. p. 41.

${ }^{15}$ ROSANVALLON, Pierre. La consagración del ciudadano. Historia del sufragio universal. México: Instituto Mora, 1999. p. 55.

${ }^{16}$ MARX, Karl. Crítica da filosofia do direito de Hegel. São Paulo: Boitempo, 2010. p. 127-135.

${ }^{17}$ Aurora Fluminense, n. 269, 23 de novembro de 1829. Evaristo da Veiga tinha parentes na região de Campanha, sul de Minas, lá radicados em 1818. Visitou a província e Campanha apenas uma vez, pouco antes de seu falecimento, e cartas enigmáticas que diziam do seu desgosto pela política sugerem uma difícil mudança conservadora, reforçada pela opção regressista dos irmãos pouco depois. Ver ANDRADE, Marcos Ferreira de. Família e política nas regências: possibilidades interpretativas das cartas pessoais de Evaristo da Veiga (1836-1837). In: RIBEIRO, Gladys Sabina; FERREIRA, Tania M. T. B. C. (org.). Linguagens e práticas de cidadania no século XIX. São Paulo: Alameda, 2010. p. 247-272.

${ }^{18}$ Cf. REZENDE, Francisco de Paula F. de. Minhas recordações, 1832-1893. Belo Horizonte: Imprensa Oficial, 1987. p. 67. OTTONI, Theophilo Benedicto. Circular dedicada aos srs. eleitores de senadores pela província de Minas Geraes. Rio de Janeiro: Typ. do Correio Mercantil, 1860. p. 2. A toupeira da história é uma imagem criada por Rosa Luxemburgo para aludir aos trabalhos subterrâneos, incessantes e silenciosos "das forças plutonianas das profundezas". Cf. LOUREIRO, Isabel. Rosa Luxemburgo. Os dilemas da ação revolucionária. São Paulo: Unesp, 1995. p. 95.

${ }^{19}$ Cf. SILVA, Wlamir. Entre un diestro nauta y ciertos espíritus traviesos: la Independencia en la provincia de Minas Gerais (18211824). Nuevo Mundo Mundos Nuevos, n. 13, 2013. Disponível em: < http://journals.openedition.org/nuevomundo/65297>. Acesso em: 10 mar. 2018.
} 
do Estado. Fatos percebidos e pensados a partir do tecido social e equacionados por meio de intricadas e tensas construções políticas pelos mineiros ${ }^{20}$. 


\section{A pedra rolada de cima da montanha...}

A Revolução do Sete de Abril e a abdicação abriram novas e graves perspectivas. Ausentava-se o inimigo comum dos liberais e se materializava o desafio do exercício do poder pela sociedade e seus representantes. Ainda às vésperas da abdicação do imperador, $O$ Universal aludia a tais perigos: "A pedra rolada de cima da montanha, ninguém sabe onde irá parar; aqueles que a tinham presa deixaram-na cair; talvez seja tarde, quando quiserem impedir os progressos da revolução que ameaça o Brasil inteiro" ${ }^{21}$. A luta contra o despotismo celeremente foi substituída pela reorganização do Estado com ênfase no sistema representativo pelo qual se completasse a preeminência do Parlamento, se estabelecesse suas relações com as dimensões continentais do país e, por conseguinte, se ampliasse a participação do povo.

Na nova conjuntura, a imprensa liberal mineira nascida no Primeiro Reinado se consolidou e se renovou $^{22}$. Seguiram os líderes surgidos no Primeiro Reinado, O Universal, de Ouro Preto, em campo até 1842, e o Astro de Minas, de São João del-Rei, resistindo até 1839. Permaneceram O Novo Argos até 1834 e a Estrela Marianense até 1832 em Ouro Preto e Mariana, e O Pregoeiro Constitucional extinto já em 1831 em Pouso Alegre. A eles somaram-se o Jornal da Sociedade Promotora da Instrução Pública (1832-1834) da capital Ouro Preto; A Legalidade em Triunfo (1833) de São João del-Rei; o Guarda Nacional Marianense (1834) e o Homem Social (1831) de Mariana; O Vigilante: Jornal da Sociedade Patriótica (1832-1835) e O Atleta Sabarense (1832) da vila de Sabará; o Opinião Campanhense (18321836) da vila de Campanha; e o Liberal do Serro (1831) do arraial do Itambé, respectivamente ao sul e ao norte de Minas.

No campo oposto, desapareceram todos os periódicos de tendência absolutista do Primeiro Reinado e surgiram outros, classificados pelos liberais como caramurus ou restauradores. Em Ouro Preto, O Grito do Povo (1833), a Gazeta de Minas (1831), O Mineiro (1833) e O Permanente (1833). Em São João del-Rei, O Constitucional Mineiro (1832-1833) e o Papagaio (1833). Alguns periódicos são de difícil caracterização, como O Tareco Militar (1833) de Ouro Preto, tido por caramuru, embora afirmasse não ser "Chimango, nem (...) Nazário"23. Na vila de Caeté surgiram o Cidadão Livre (1831), O Relâmpago (1833) e o Despertador Mineiro (1833), todos sem acervo, envolvidos na sedição de 1833, além de O Exorcista (1833) e do Tribuno do Serro (1833) de Diamantina, e do Noticiador Serrano (1833) da vila do Príncipe.

É significativo que a imprensa liberal-moderada tivesse grande consciência da complexidade da opinião pública e da sua importância pedagógica no "comércio de pensamentos". O Universal, em fins de 1832, fez uma síntese impressionante disso: a consciência da capacidade da escritura de romper distâncias ${ }^{24}$, permitir que o tempo resfriasse o entusiasmo dos embates e o cotejamento de escritos opostos e com "juízos pronunciados simultaneamente em diversos lugares por homens que não podiam mancomunar-se"; a quebra dos limites dos pequenos círculos, típicos do Antigo Regime, e o esboço de uma vida política orientada por conceitos e a difusão de uma nova cultura política. Assim, aspiravam constituir uma "opinião geral", moldar a opinião pública, contornar a reprovação e dar-lhe uma direção ${ }^{25}$. A criação de uma rede de periódicos por vilas e arraiais divulgou os preceitos liberais entre os "simples" ${ }^{26}$ ou "em prol do rústico", expressão que já comentamos e indica uma compreensão

\footnotetext{
${ }^{21}$ O Universal, n. 576, 30 de março de 1831.

${ }^{22}$ Para a imprensa mineira no Primeiro Reinado ver SILVA, Wlamir. Princípios substanciais, circunstâncias acidentais: da gênese do liberalismo moderado na imprensa mineira do Primeiro Reinado (1825-1831). In: FONSECA, Silvia Carla P. de B.; CORREA, Maria Letícia (org.). 200 anos de imprensa no Brasil. Rio de Janeiro: Contra Capa, 2008, e SILVA, WLAMIR. A imprensa e a pedagogia liberal na província de Minas Gerais (1825-1842). In: FERREIRA, Tânia. Maria B. da C.; MOREL, Marco; NEVES, Lúcia Maria B. P. (org.). História e imprensa: representações culturais e práticas de poder. Rio de Janeiro: DP\&A/ Faperj, 2006.

${ }^{23}$ O Tareco Militar, n. 1, 27 de julho de 1833.

${ }^{24}$ Quaes são os bens e os males que podem resultar da liberdade da Imprensa; e qual he a influencia que eles podem ter no momento em que os Representantes da Nação Portuguesa se vão congregar? In: CARVALHO, José Murilo; BASTOS, Lúcia; BASILE, Marcello (org.), Op. Cit., p. 205-206.

${ }^{25}$ A expressão “comércio de pensamentos” é de BEAUZÉE, Nicolas. Língua (Gramática). In: DIDEROT, Denis; D’ALEMBERT, Jean Le Rond. Enciclopédia, ou Dicionário razoado das ciências, das artes e dos ofícios, vol. 2: O sistema dos conhecimentos. São Paulo: Unesp, 2015. p. 377. Cf. O Universal, n. 815, 17 de outubro de 1832. Apud SILVA, Wlamir. Liberais e povo: a construção da hegemonia liberal-moderada na província de Minas Gerais (1830-1834). São Paulo: Hucitec, 2009. p. 128.
}

${ }^{26}$ GRAMSCI, Antônio. Cadernos do cárcere..., vol. 1, Op. Cit., p. 100-104. 
espontânea do fenômeno ${ }^{27}$ para o que não faltava a consciência das dificuldades frente à rusticidade e, mais, às permanências da velha sociedade, às hierarquias, ao simbolismo monárquico e ao fanatismo religioso $^{28}$. Os integrantes desta sociabilidade atuavam como uma elite intelectual num sentido amplo, engajados na difusão de seu projeto político e na nova cultura política da sociedade mineira ${ }^{29}$.

São eles: entre os liberais, um padre, professor e advogado provisionado, como José Antônio Marinho, do Astro de Minas, do Jornal da Sociedade Promotora da Instrução Pública, da Oposição Constitucional e do Americano; o padre e bibliotecário Francisco de Assis Braziel, do Astro de Minas; o bacharel em Direito e juiz substituto João Nepomuceno Aguilar do Diamantino e do Echo do Serro; o médico e fazendeiro dr. Camillo Maria Ferreira Armonde do Echo da Razão; o ourives e tipógrafo autodidata Manuel Sabino de Sampaio Lopes no Echo do Serro; Eleitor Fortunato (Luiz Fortunato de Souza Carvalho), burocrata, do Guarda Nacional Mineiro; Teófilo Benedito Otoni, comerciante e empreendedor, do Sentinela do Serro; o ourives e tipógrafo autodidata Geraldo Pacheco de Melo do Liberal do Serro; Herculano Ferreira Penna, professor e burocrata, do Novo Argos; o padre e professor Antônio José Ribeiro Behring também do Novo Argos; o negociante Bernardo Jacinto da Veiga da Opinião Campanhense; o padre e fazendeiro José Bento Leite Ferreira de Mello do Pregoeiro Constitucional e do Recopilador Mineiro; o magistrado e político Bernardo Pereira de Vasconcelos do Universal; o bacharel em Direito Joaquim Antão Soares Leão do Universal; o advogado provisionado e burocrata José Pedro Dias de Carvalho também do Universal; e os militares coronel Pedro Gomes Nogueira e tenente Antônio Pereira da Fonseca do Vigilante.

Entre os redatores caramurus estavam padres como Luiz José Dias Custódio da Ordem e, antes, o padre "Verruga" do Amigo da Verdade; Francisco Freire de Carvalho, padre e ex-professor de História e Antiguidades de Coimbra, do Constitucional Mineiro; o comerciante Manoel Soares do Couto e o fazendeiro Antônio Gomes Cândido do Correio de Minas; o médico cirurgião dr. Jacintho Rodrigues Pereira Reis do Despertador Mineiro; o escrivão Antônio Gomes Batista do Estafeta; o padre Marciano Gomes Batista também do Estafeta; o burocrata José Gonçalves Cortes do Telegrapho e do Grito do Povo; o padre Justiniano da Cunha Pereira do Parahybuna; e o tenente e negociante Francisco Magalhães Gomes do Tareco Militar ${ }^{30}$.

\footnotetext{
${ }^{27}$ Pregoeiro Constitucional, n. 1, 7 de setembro de 1830.

${ }^{28}$ Astro de Minas, n. 726, 21 de julho de 1832.

${ }^{29}$ Ver SILVA, Wlamir. Liberais e povo..., Op. Cit., capítulo 3.

${ }^{30}$ GRAMSCI, Antônio. Cadernos do cárcere..., vol. 2, Op. Cit., p. 25. Para um quadro dos redatores de periódicos do período ver SILVA, Wlamir. Imprensa e opinião pública no Brasil Império: Minas Gerais e São Paulo (1826-1842). 300 f. Tese (Doutorado em História), Faculdade de Filosofia e Ciências Humanas, Universidade Federal de Minas Gerais, Belo Horizonte, 2011. p. 204-205. Para as ocupações ver VEIGA, José Pedro X. da. Ephemerides mineiras (1664-1897). Belo Horizonte: Centro de Estudos Históricos Culturais/Fundação João Pinheiro, 1998, e SILVA, Wlamir. Liberais e povo..., Op. Cit., capítulo 3. Sobre Francisco Freire de Carvalho, cremos ser o autor de Fabulas moraes e politicas do poeta Filósofo persa Saady, e Portuguez emigrado, conforme o Constitucional Mineiro de janeiro de 1833, apresentado pelo Astro de Minas em 1830 como padre, ex-professor de História e Antiguidades na Universidade de Coimbra e de Retórica e Poética “em um dos Geraes de Lisboa”, prestes a instalar um curso de Humanidades na vila de São João del-Rei, e dado como redator do referido periódico. Cf. MOREIRA, Luciano da Silva. Leituras na província: impressos e práticas de leitura na província de Minas Gerais (1828-1842). In: SIMPÓSIO NACIONAL DA ASSOCIAÇÃO DOS PROFESSORES DE HISTÓRIA, 2007, Florianópolis. Anais do XXIV Simpósio Nacional da Associação dos Professores de História. São Paulo: ANPUH, Florianópolis, 2007. p. 3. Disponível em: <http://anais.anpuh.org/wp-content/ uploads/mp/pdf/ANPUH.S24.0944.pdf>. Acesso em: 15 mar. 2018, e o Astro de Minas, n. 369, 30 de março, n. 375,15 de abril de 1830, e n. 774, 13 de novembro de 1832. Sobre Antônio Gomes Cândido ver SELINGARD, Cristóvão. Educação religiosa, disciplina e poder na terra do ouro: a história do Seminário de Mariana, entre 1750 e 1850. 222 p. Dissertação (Mestrado em Educação), Universidade Federal de São Carlos, São Carlos, 2007. Sobre Jacintho Rodrigues Pereira Reis, cf. Dicionário histórico-biográfico das ciências da saúde no Brasil (1832-1930). Disponível em: < http://www.dichistoriasaude.coc.fiocruz.br/ $\mathrm{iah} / \mathrm{pt} / \mathrm{verbetes/reisjarope.htm \# dados>}$. Acesso em: 15 mar. 2018. Sobre João Nepomuceno Aguilar, o mesmo foi juiz municipal substituto, cargo que exigia, pelo Código de 1832, ser bacharel ou, ao menos, pessoa conceituada e instruída, cf. MARIANO, Delsa de Fátima dos Santos. Escravos e libertos: autores de ações de liberdade em Diamantina (1850-1851). 119 f. Dissertação (Mestrado profissional interdisciplinar em Ciências Humanas), Universidade Federal dos Vales do Jequitinhonha e Mucuri, Diamantina, 2015. p. 82-113, e NASCIMENTO, Alexsandro R. A justiça quase perfeita: discussões sobre os juízes municipais na Comarca do Recife. In: SIMPÓSIO NACIONAL DE HISTÓRIA, 2013, Natal. Anais do XXVII Simpósio Nacional de História, Natal, 2013. Para os ourives Manuel Sabino de Sampaio Lopes e Geraldo Pacheco de Melo, cf. MOREIRA, Luciano. Imprensa e opinião pública..., Op. Cit., p. 167-181, 208-209. Cremos que o "Eleitor Fortunato", citado por Moreira, seja Luiz Fortunato de Souza Carvalho, cf. PAULA, Alexandre Marciano de. O Regresso em Minas Gerais: “déspotas e republicanos" na imprensa mineira (1837-1840). 170 f. Dissertação (Mestrado em História), Universidade Federal de São João del-Rei, São João del-Rei, 2013. p. 54-65. Identificamos como redator do Tareco Militar Francisco Magalhães Gomes, e não João Martins de Moura Duque Estrada como indica Moreira; e não conseguimos identificar tal personagem. Nos mapas de população de Ouro Preto Francisco Gomes aparece como tenente e negociante, proprietário de três escravos, cf. SILVA, Wlamir. Liberais e povo..., Op. Cit., p. 312. Nossos estudos não confirmam
} dossiê Regência e Imprensa 
Um quadro variado e indistinto de intelectuais, os quais não se divisa pela ocupação a tendência política, havendo padres, proprietários e bacharéis em ambos os lados do espectro político e ainda a presença de pardos que, pelo esforço jornalístico, visavam o convencimento de camadas mais amplas da população, nas quais as relações de origem e as relações pessoais seriam ainda mais dispersas e suscetíveis à peroração relativamente impessoal e abstrata dos conceitos em disputa. Ainda mais que o alcance da escritura contornava o analfabetismo e o não letramento por meio da oralidade ampliada pela sociabilidade da qual temos boa notícia, franqueando-se periódicos em casas, como a do padre Bhering, redator do Novo Argos, para leituras públicas. Eram espaços, momentos e ambientes nos quais se pode imaginar uma intensa sociabilidade política. ${ }^{31}$

\section{O horizonte}

Em maio de 1831, O Universal publicou um texto cheio de súplicas a Deus, no qual "a brilhante luz de felicidade (...) que jamais se viu despontar no seu horizonte político" convivia com "nevoeiros e (...) tempestades ameaçadoras" 32 . O horizonte de mudanças e a divisão dos liberais em moderados e exaltados redimensionaram temas como República e federalismo. Afirmar-se-ia então a moderação, seus conceitos e projeto: a defesa da monarquia; a compreensão da República como possibilidade distante, em perspectiva evolucionista e retórica; o aprofundamento da construção das identidades sociais e políticas, com a imagem dos liberais moderados ligada à propriedade, às luzes e à virtude, em oposição aos caramurus, faltos das mesmas qualidades, e aos exaltados, anárquicos incitadores de incautos e ignorantes; a identificação de pardos e liberais, conquistando grupos significativos da sociedade, em oposição à imagem do escravo infantil e perigoso, em disputa com os caramurus ${ }^{33}$.

Os liberais moderados lograram a direção política da sociedade mineira. Dominaram a província e elegeram deputados que representaram a moderação no âmbito nacional, conduziram a população e puseram-se à margem das turbulências mais graves do período regencial. Sua hegemonia iria, de fato, aprofundar-se na repressão à sedição de 1833 ocorrida na capital Ouro Preto. Ali, a imprensa moderada reforçou a identidade liberal da província, delineando como restaurador um movimento que reunia insatisfações diversas, entre as quais supostas arbitrariedades dos moderados, a proibição de enterros na igreja, a taxação da aguardente e, mesmo, a participação de antigos pertencentes à moderação. Fez valer sua pedagogia e impôs sua interpretação do movimento, identificando-os a qualquer "anarquia". Caracterizaram os sediciosos como socialmente desimportantes, "monstros", "canibais" e "antropófagos" ${ }^{4}$, levando às raias da teratologia a imagem dos seus adversários. A vitória moderada ensejou a coerção pelo poder provincial, coadjuvado pelo poder central, e sepultou quaisquer vicissitudes contrárias, restauradoras e - quem sabe? - exaltadas ${ }^{35}$.

Mas tal hegemonia não foi isenta de contradições e interdições. Destaque-se a questão das reformas constitucionais, central para as divergências entre exaltados, caramurus e moderados. A historiografia tem afirmado que as reformas teriam sido próprias dos exaltados, em especial no que tange ao elemento federativo e do federalismo, em oposição à defesa da intocabilidade da Constituição pelos caramurus. Os moderados seriam contrários às reformas, às quais apenas teriam tolerado com vistas ao apoio dos exaltados, temidos pela influência nas ruas da Corte e nas províncias, redundando na forma mitigada do Ato Adicional ${ }^{36}$. A relação da imprensa moderada mineira com as reformas constitucionais foi

a hipótese de redação do Companheiro do Conselho por Bernardo Pereira de Vasconcelos, como indicado por Octavio Tarquínio de Souza. Para Geraldo Pacheco de Melo ver Traços biographicos de serranos ilustres, já falecidos. Revista do Arquivo Público Mineiro, Belo Horizonte, vol. 1, 1905. Sobre o tenente Antônio Pereira da Fonseca ver SANTOS, Marileide Lopes dos. Educação, assistência e sociabilidade: o governo dos pobres em Sabará/MG (1832-1860). 200 f. Dissertação (Mestrado em Educação), Faculdade de Educação, Universidade Federal de Minas Gerais, Belo Horizonte, 2007. p. 93.

${ }^{31}$ O Universal, n. 398, 1 de fevereiro de 1830, n. 581, 13 de abril, n. 583, 18 de abril de 1831, e n. 667, 2 de novembro de 1831; Estrela Marianense, n. 64, 6 de agosto de 1831. Ver MOREIRA, Luciano. Imprensa e opinião pública no Brasil Império..., Op. Cit., p. 235.

${ }^{32}$ O Universal, n. 600, 30 de maio de 1831.

${ }^{33}$ Cf. SILVA, Wlamir. Liberais e povo..., Op. Cit.

${ }^{34}$ O Novo Argos, n. 185, 12 de outubro de 1833.

${ }^{35}$ SILVA, Wlamir. Liberais e povo..., Op. Cit., capítulo 7.

${ }^{36}$ Ver BASILE, Marcello. O Império em construção: projetos de Brasil e ação política na Corte imperial. 2004.490 f. Tese (Doutorado em História Social), Instituto de Filosofia e Ciências Sociais, Universidade Federal do Rio de Janeiro, Rio de Janeiro, 2004. p. 66 e 213, e O "negócio mais melindroso": reforma constitucional e composições políticas no Parlamento regencial (1831-1834). In: 
de fato claudicante, em especial com a difusão simbólica do federalismo. No seio da província, o federalismo não adquiria os contornos radicais de outras partes do Império, nas quais se identificava ao liberalismo exaltado ou aos excessos do Norte e, posteriormente, do Sul. A federação tinha mesmo simpatias expressas na imprensa moderada. A princípio, pois, predominaria uma renitente dubiedade com relação às reformas e sua circunscrição aos trâmites legais.

As reformas foram luz e nevoeiros para a moderação mineira. Um assunto delicado, em especial pelo mote do federalismo, cujas origens estavam no Norte, mas que não estavam ausentes da experiência mineira da Independência ${ }^{37}$. No entanto, o federalismo tornou-se bandeira dos exaltados e isso cravejou de estigmas a ideia, reforçando o mal-estar criado pelas denúncias do federalismo do imperador em Minas. Classificada ainda antes do Sete de Abril pelo Universal como "bulha da Corte" 38 , e negada pelo Astro de Minas, dias antes - "[n]a Província de Minas não se tratou de Federação [que] essas ideias nasceram no Rio de Janeiro, e (...) não se propagaram por alguma outra parte" -, isso não impediria que, já em meados de 1831, as reformas fossem saudadas como oportunidade de reconfiguração do Estado, pelo mesmo Astro, as "úteis reformas". Mas o perigo de dissolução do "edifício social” pela República e pela democracia se impôs, atrelado ao federalismo, restando a posição dúbia de defesa da sua legalidade, da não criminalidade do federalismo e do vezo de relativizar a sua importância diante, inclusive, de clamores federalistas entre os mineiros. Intentava-se, sem muito êxito, definir uma pauta moderada e mais prudente de reformas, avessa a extremos "cativos" ou republicanos, ancorada na já assentada identidade mineira ${ }^{39}$.

O Novo Argos foi sensível ao tema pela "perda de muitos assinantes" depois que "se enunciou muito terminantemente contra a Federação proposta pelo Repúblico". Tomou à frente da questão para atender tal demanda, o que teria conseguido. Defenderia protocolarmente o direito às reformas previstas na Constituição e sustentaria um fortalecimento dos conselhos provinciais, lista tríplice para a indicação do presidente de província e outras autoridades e julgamento dos presidentes e juízes de direito por justiças ordinárias ou pelo Conselho Geral da província. Declara que "não insiste em questão de palavras", deixando clara a preocupação com o peso simbólico da Federação ${ }^{40}$ e buscando esvaziá-lo. A delicadeza do tema era denunciada pelo Mentor das Brasileiras, que negava o federalismo e defendia a federação por meios legais ${ }^{41}$. A cautela capitaneada pelo Universal, que não as combate nem sustenta, por prematuras, e às quais se refere de modo impreciso, daria o tom à pedagogia moderada, no mais crítico às mesmas e alinhada à moderação da Corte e à necessidade de sustentar o governo frente a supostos riscos de separação de províncias, mesmo frente a demandas populares. Em síntese, "a revolução está acabada; (...) nem um passo fora da Constituição" 42 , a estrita legalidade seria o mote distintivo dos exaltados da Corte, alcançando em boa parte a opinião pública ${ }^{43}$, o que significava a transferência das reformas para a Legislatura seguinte e a execução daquelas já conhecidas da sociedade ${ }^{44}$.

Estrita legalidade que, no entanto, não impedia a ameaça ao Senado de perder seus postos "não pelos meios legais", mas pela vontade soberana da nação ${ }^{45}$. Ou seja, que os corifeus moderados não

NEVES, Lúcia Maria B. P. das (org.). Livros e impressos: retratos dos Setecentos e dos Oitocentos. Rio de Janeiro: Eduerj, 2009. p. $185-219$.

${ }^{37}$ Cf. GUIMARÃES, Lúcia Maria Paschoal et al. Republicanos ou federalistas. In: ENCONTRO REGIONAL DA ANPUH-RJ, 1990, Rio de Janeiro. História hoje: balanço e perspectivas. Anais do IV Encontro Regional da ANPUH-RJ, Rio de Janeiro, 1990, e LYRA, Maria de Lourdes Viana. Centralisation, systeme fiscal et autonomie provinciale dans l'Empire brésilien: la province da Pernambuco - 1808-1835. Paris: Universidade de Paris X, 1985.

${ }^{38}$ O Universal, n. 570, 16 de março de 1831.

${ }^{39}$ O Universal, n. 648, 19 de setembro de 1831; o Astro de Minas, n. 515, 12 de março de 1831, n. 516, 15 de março de 1831 , e n. 519, 22 de março de 1831; O Novo Argos, n. 68, 1 de março de 1831, n. 69, 10 de março de 1831; O Novo Argos, n. 71 , 26 de março de 1831; O Universal, n. 580, 11 de abril de 1831, n. 595, 16 de maio de 1831, e n. 606, 13 de junho de 1831.

${ }^{40}$ O Novo Argos, n. 68, 1 de março, e n. 71, 23 de março de 1831.

${ }^{41}$ Apud $O$ Universal, n. 583, 18 de abril de 1831.

${ }^{42}$ Ibidem, n. 582, 15 de abril de 1831. Em 18 de abril, $O$ Universal dizia da chegada da notícia da abdicação em Ouro Preto em 15 de abril, portanto, no número do mesmo dia 15 esta informação não devia ser conhecida, cf. n. 583, 18 de abril de 1831 . Ver também o Universal, n. 605, 10 de junho de 1831.

${ }^{43}$ Astro de Minas, n. 567, 14 de julho, n. 632, 12 de agosto, e n. 644, 9 de setembro de 1831.

${ }^{44}$ Ibidem, n. 648, 19 de setembro de 1831.

${ }^{45}$ Ibidem, n. 657, 1 de outubro de 1831. 
balançassem ante as pressões populares. O Universal chegaria a admitir em meados de 1831 que viriam reformas em "sentido federal". Já em meados de 1832, o Astro de Minas, segundo mais importante da província, publicaria, uma série de artigos de $O$ Federalista, donde se depreendiam aspectos positivos do sistema: 
Finalmente, pode-se estabelecer como regra, apesar de uma ou outra exceção, que todo poder, cuja responsabilidade está longe do foco das suas ações, é infalivelmente mais, ou menos, arbitrário e por consequência sempre pesado aos Povos. Não será assim com o regime federativo. As autoridades escolhidas pelo mesmo Estado onde tem de exercer as suas funções vem a responsabilidade iminente, como Dâmocles tinha a espada que o devia punir pendente por um fio sobre a sua cabeça ${ }^{46}$.

O projeto de reformas foi aprovado com apoio moderado, e previa a monarquia federativa e a extinção do Poder Moderador, da vitaliciedade do Senado e do Conselho de Estado ${ }^{47}$. Pressionados ou não, os moderados o subscreveram, voto necessário para a maioria na Câmara, e não repeliram o conteúdo das reformas, mas o contexto conflituoso que circundava o "federalismo". Já nos primeiros dias de 1832, O Universal replicava o Astro em defesa tímida: "se não destrói um governo, quando se o reforma”. É fato, no entanto, que a imprensa moderada abdicou de defendê-las no âmbito e a partir de Minas, mesmo sob a sua hegemonia, temendo a influência exaltada ${ }^{48}$, o que contrariava demandas oriundas do próprio processo de Independência que se insinuaram nas Juntas Governativas criadas pelas Cortes de Lisboa, estiveram presentes nos esforços constituintes e na luta da oposição liberal desde o Primeiro Reinado, com a criação dos conselhos provinciais, que eram ensaios de sistema federativo, com divisão das receitas geral e provincial, um sistema representativo e uma "cultura legislativa" ${ }^{49}$. Não à toa o federalismo estadunidense, em condições geográficas semelhantes, se tenha constituído em paradigma do sistema representativo ${ }^{50}$, represado no seio do Laboratório da Nação, limitando o horizonte da participação ativa dos cidadãos ${ }^{51}$.

O Pregoeiro Constitucional tentaria desmistificar a Federação, exatamente pela via do pacto social, da relação entre sociedade e Estado: "Confederação ou como quiserem chamar, sistema federativo nada mais é do que uma sociedade comum (...). O modo de se constituírem os Estados em uma sociedade Federativa é o mesmo que se observa na organização de um só Estado (...). Forma-se a Lei, ou Pacto Fundamental, onde se marca o modo porque os Estados devem ser governados" ${ }^{52}$. A Sentinela do Serro, de Teófilo Otoni, em sua proposta de "lentamente republicanizar a constituição do Brasil", destacava o papel das assembleias provinciais nos esforços de manterem-se os liberais "na representação nacional" 53 .

\footnotetext{
${ }^{46}$ O Universal, n. 626,29 de julho de 1831, e o Astro de Minas, n. 716, 28 de junho de 1832.

${ }^{47}$ O Projeto Miranda Ribeiro é reproduzido, a título de programa do Partido Liberal, em BRASILIENSE, Américo. Os programas dos partidos e o Segundo Império. Brasília, Senado Federal; Rio de Janeiro, Fundação Casa de Rui Barbosa, 1979, p. 18-20.

${ }^{48}$ Apud $O$ Universal, n. 695, 9 de janeiro, e n. 704, 30 de janeiro de 1832.

${ }^{49}$ OLIVEIRA, Carlos Eduardo F. de. Construtores do Império, defensores da província: São Paulo e Minas Gerais na formação do Estado nacional e dos poderes locais. Tese (Doutorado em História), Departamento de História, Faculdade de Filosofia, Letras e Ciências Humanas, Universidade de São Paulo, São Paulo, 2014. p. 21, 115-116, 118, 128 e 144.

${ }^{50}$ MANIN, Bernard. Los princípios del gobierno representativo..., Op. Cit., p. 162.

${ }^{51}$ Ver COSER, Ivo. O conceito de federalismo e a ideia de interesse no Brasil do século XIX. Dados - Revista de Ciências Sociais, Rio de Janeiro, vol. 51, n. 4, p. 941-981, 2008, e Idem. O pensamento político dos liberais: o conceito de americanismo na construção do Estado brasileiro. Perspectivas: Revista de Ciências Sociais, São Paulo, Unesp, vol. 38, p. 49-73, 2010. Disponível em: <http:// seer.fclar.unesp.br>. Acesso em: 15 mar. 2018; CURIEL, Carole. De los muchos, uno: el federalismo en el espacio ibero-americano; THIBAUD, Clément. Federalismo - Colômbia; ÁVILA, Alfredo. Federalismo - Colômbia. In: SEBASTIÁN, Javier Fernández (dir.). Diccionario político y social del mundo ibero-americano. La era de las revoluciones, 1750-1850 [Iberconceptos-I]. Madri: Fundación Carolina; Sociedad Estatal de Conmemoraciones Culturales; Centro de Estudios Políticos y Constitucionales, 2009. p. 425-450, 486-497 e 506-516. CARVALHO, José Murilo de. Federalismo y centralización en el Imperio brasileño: historia y argumento. In: CARMAGNANI, Marcello (coord.). Federalismos latinoamericanos: México/Brasil/Argentina. México, DF: Fondo de Cultura Económica, 1993. p. 75.

${ }^{52}$ Pregoeiro Constitucional, 23 de março de 1831. Apud OLIVEIRA, Françoise Jean de. Discursos impressos de um padre político: análise da breve trajetória d'O Pregoeiro Constitucional. Almanack Braziliense, n. 5, maio 2007.

${ }^{53}$ O Novo Argos, 8 de julho de 1830, 1 e 10 de março de 1831; o Astro de Minas, 12 de março de 1831; O Pregoeiro Constitucional, 5 de fevereiro e 2 de abril de 1831; O Universal, 16 de março de 1831; e o Sentinela do Serro, 25 de junho de 1831.
} 


\section{Ícaros com asas de cera}

Em abril de 1831, em meio às desinteligências sobre os meios de encaminhar reformas e o incômodo com o peso simbólico do tema, um correspondente do Universal, cognominado "O Jovem Brasileiro", questionava, apoiado na legalidade da previsão de reformas contida no artigo 174 da Carta: "é crime dar-se Vivas à Federação?"54 Os meros "vivas" não o seriam, argumentaram aqui e ali as folhas moderadas, mas a criminalização não foi descartada para o enquadramento dos mais radicais, indo além da fraterna dissenção liberal a tibieza para com as reformas. Foi o caso do periódico tijucano Diamantino, que defendera as reformas sem o Senado em termos duríssimos: "Queremos antes ver a Nação sucumbir vítima do nosso mesmo furor do que escrava de meia dúzia de parasitas". Com o Diamantino, O Universal se conformaria com a advertência, ao menos não há notícias a mais. E, ainda titubeante, se afirmaria desejoso das reformas e "panegirista da federação", admirador dos Estados Unidos e apenas crítico do uso da força, pelo risco de uma "guerra civil"

Mas a prática se endureceria com a proposta da Sociedade Promotora do Bem Público, veiculada pelo periódico Sentinela do Serro, ambos da vila do Príncipe e sob a influência de Teófilo Otoni, vizinhos, aliás, do tijucano Diamantino. Propuseram eles a delegação de poderes constituintes para a aprovação do projeto à próxima legislatura da Câmara eletiva, a antecipação daquela legislatura e a exclusão do Senado do processo decisório, caso ele postergasse ou rejeitasse as reformas. E, ainda, a mobilização das municipalidades e sociedades patrióticas do Império para que, nos círculos eleitorais, fossem estabelecidos tais "poderes constituintes". No introito do documento, avançavam que "os amigos (...) da felicidade pública" trabalhavam "por extinguir as instituições europeias, que se pretendem enraizar entre nós", sem deixar de ver neles o defeito de por vezes "precipitá-las em demasia ocasionando desordens". Ao ofício da Sociedade Promotora do Bem Público seguia um artigo do Sentinela do Serro que afirmava o desejo da nação pelas "reformas federais e democráticas", mesmo que isso fosse contra "as ordens dos Turcos do Senado", e ia bem além: "Se o Senado não descer, deve cair"56.

Já em março de 1832, O Universal anunciava a interrupção dos trabalhos da Sociedade Promotora do Bem Público e da Sentinela do Serro. A Sociedade Promotora do Bem Público "qual Ícaro com asas de cera quis[era,] voar à altura do Sol", sofrendo "de todas as partes (...) o grito de reprovação". A Sentinela do Serro é elogiada pelos serviços "durante o reinado de Pedro Bourbon" e logo acusada "de querer desde já a República (...) Alucinada com as belas teorias do Governo democrático". A reação às duas instituições é atribuída ao "Povo [que] se levantou" contra os excessos "de uma massa popular". Mais que o teor da proposta, a ousadia do Ícaro serrano estaria em sua diligência em oficiar a câmaras e sociedades, dentro e fora da província, justificando o castigo exemplar.

Em abril, O Novo Argos respondia a um ofício de um juiz de paz da vila do Príncipe que informava a interrupção das atividades da Sociedade Promotora do Bem Público e da Sentinela do Serro. No ofício, ele se queixava da "impolítica e acre resposta" da Sociedade Promotora da Instrução Pública de Ouro Preto e de a mesma haver animado "telegráficos" a promoverem roubos e a acusarem a Sociedade Promotora do Bem Público de "republicanos". Repelindo o repto, o redator do Novo Argos reportava à Sociedade Promotora do Bem Público de São João del-Rei, além da câmara de São José, e, mesmo, à Defensora do Rio de Janeiro, "que se julgou ofendida no seu melindre pelo Ofício da Sociedade da Vila do Príncipe (...), que nele descobriu um meio de se ilaquearem as municipalidades e Associações Patrióticas para uma sedição, que talvez tivesse por fim a queda do mesmo Código Fundamental"57. Dizia ainda que a Sociedade Promotora da Instrução Pública de Ouro Preto "rebateu proposições que lhe pareceram subversivas da Ordem" 58 . A câmara de São José não só repeliu, decidindo "não responder tal papel" e qualificando-o como anárquico e sedicioso, como encaminhou ofício ao presidente da

\footnotetext{
${ }^{54}$ O Universal, n. 580,11 de abril de 1831.

${ }^{55}$ O Universal, n. 723, 10 de março de 1832. O mesmo argumento do perigo da "guerra civil" está no n. 765, 22 de junho de 1832 , e no Astro de Minas, n. 693, 5 de maio de 1832.

${ }^{56}$ Representação da Sociedade Promotora do Bem Público, estabelecida na vila do Príncipe, em 2 de fevereiro de 1832 , e artigo do Sentinela são reproduzidos no Astro de Minas, n. 669, 8 de março de 1832 . O ofício é reproduzido também em OTTONI, Theophilo Benedicto. Circular dedicada aos srs. eleitores de senadores pela província de Minas Geraes..., Op. Cit., p. 23-24.

${ }^{57} \mathrm{O}$ parecer da Sociedade Defensora do Rio de Janeiro é reproduzido no Astro de Minas, n. 674, 20 de março de 1832.

${ }^{58}$ O Novo Argos, n. 125, 6 de abril de 1832.
} 
província para providências ${ }^{59}$.

A dureza da rejeição à ousadia serrana completar-se-ia com a Sociedade Promotora da Instrução Pública que repeliu seu vezo revolucionário, ilegal e "para destruir a Constituição"60. A Sociedade Patriótica Marianense foi mais cordata, protestando amizade e uniformidade de sentimentos. Ainda que rejeitando o meio revolucionário, refere-se ao convite "para uma resistência formal ao Senado" evitando ali a suspeita da ação armada ${ }^{61}$. A Sociedade Patriótica do Desterro, província de Santa Catarina, rejeitaria e afirmaria o trilho da legalidade contra os horrores da guerra civil do "punhal legicida", secundada por um periódico local ${ }^{62}$. A Câmara de Baependi considerava o convite inadmissível, criticava a revogação da assembleia em curso, a "revolução irmã gêmea da anarquia" e atribuía a origem do objeto ao deputado Luiz Augusto May, redator do incendiário Malagueta ${ }^{63}$. A Câmara de Pitangui rejeitou os "meios (...) injustos, impolíticos, ilegais e anárquicos" ${ }^{4}$. Seriam feitas instâncias junto aos poderes provinciais e judiciários, buscando-se criminalizar a iniciativa, classificada como não representativa da opinião geral, do voto popular, e o artigo do Sentinela do Serro levado ao Tribunal do Júri ${ }^{65}$.

O rebaixamento da Sociedade Promotora do Bem Público e da Sentinela do Serro foi divulgado exemplarmente e associado ao risco de "uma revolução violenta" e da dissolução do "Corpo da Nação" ${ }^{\text {. }}$ Mas era preciso calcinar o Ícaro serrano. Aproveitando-se da brecha criada pelo "extinguir as instituições europeias", O Universal sugeriria que o "elemento europeu (...) é a Monarquia Constitucional", insinuando a intenção revolucionária republicana. O Novo Argos, na mesma senda, referia-se a contradições do Sentinela do Serro "que no seu N. 80 negou a existência de um Imperador no Brasil, e sustentou a necessidade de se extinguir a Monarquia, havendo confessado poucos dias antes que (...) bastariam as reformas" ${ }^{\prime 6}$. Talvez se referisse a um trecho que fora reproduzido pelo Constitucional Mineiro, periódico caramuru de São João del-Rei: "Quem impera ou governa é a Regência, e não o Imperador, que não o é ainda de fato. Virá a ser, terminada a minoridade, se a Nação antes disso não reafirmar a Constituição, e extirpar dela o elemento Europeu, o que nos parece indispensável... porque o Dia 7 de Abril derrubou no Brasil a o monarquismo!!!”.

Mas não se limitaria ao "norte interno" a insatisfação com a frustração reformista pela estrita legalidade. Do sul mineiro partiria, em associação com setores moderados da Corte, o golpe parlamentar intentado em 30 de julho de 1832, a "revolução dos três padres"68 - dois deles mineiros do sul - que propunha a transformação da Câmara dos Deputados em uma Assembleia Constituinte restrita, sem o Senado, como já o haviam feito os liberais serranos. Conspiração urdida na chácara da Floresta do padre Custódio Dias, proprietário na região que é hoje Alfenas, para a demissão coletiva do Ministério e da Regência e a transformação em assembleia nacional, com fito de aprovar a já redigida "Constituição de Pouso Alegre". O golpe parlamentar moderado, apoiado na mobilização de guardas nacionais da Corte, juízes de paz e do povo nas galerias e nos arredores da Câmara, foi frustrado pela divisão moderada ${ }^{69}$.

A "Constituição de Pouso Alegre" fora impressa na tipografia do Pregoeiro Constitucional, de propriedade de José Bento Leite Ferreira de Melo, o segundo padre do sul de Minas - de Pouso Alegre - da conspiração. Françoise Jean de Oliveira destacou que O Pregoeiro se empolgara pouco após a abdicação com as reformas, incluso o modelo federativo democrático com inspirações

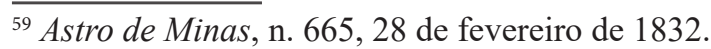

${ }^{60}$ Suplemento a $O$ Universal, n. 721, 9 de março de 1832.

${ }^{61}$ Estrela Marianense, n. 95, 31 de março de 1832.

${ }^{62}$ O Novo Argos, 15 de maio de1832.

${ }^{63}$ O Novo Argos, n. 127, 24 de abril de 1832.

${ }^{64} \mathrm{O}$ Universal, n. 761, 13 de junho de 1832.

${ }^{65}$ O Universal, n. 762, 5 de junho de 1832 e O Novo Argos, n. 126, 13 de abril de 1832.

${ }^{66}$ O Universal, n. 771, 6 de julho de 1832; no mesmo sentido ver o Astro de Minas, n. 726, 21 de julho de 1832 , e Opinião Campanhense, n. 8, 22 de junho de 1832.

${ }^{67}$ O Universal, n. 733, 4 de abril de 1832, e O Novo Argos, n. 126, 13 de abril de 1832.

${ }^{68}$ Eram os padres o ministro da Justiça, Diogo Antônio Feijó, e os deputados mineiros José Custódio Dias e José Bento Ferreira de Mello. SOUZA, Octávio Tarquínio de. Três golpes de Estado. Belo Horizonte: Itatiaia; São Paulo: Edusp, 1988. p. 82-106.

${ }^{69}$ Ibidem, p. 92.
} 
estadunidenses, liberdade de escolha de seus presidentes e tendo em vista o tamanho do território brasileiro $^{70}$. Seu último número é o de 4 de junho de 1831, uns três meses depois do imbróglio dos Ícaros serranos. Ainda em 28 de maio, o Pregoeiro defendia com denodo a federação, relativizando a monarquia constitucional como impeditiva para sua instalação, "embora qualquer de seus antigos defensores desista da empresa". Em seu último número conhecido, de junho, prega que "o Brasil não pode nem deve ficar estacionário", adianta-se às necessidades de um "poder executivo com força moral e energia" e rebate os que "mui erradamente pensam [que os que seguem] querendo a reforma (...) exigem a fraqueza do governo" ${ }^{\prime 1}$. É plausível que o Pregoeiro tenha desaparecido para contornar o enquadramento que vitimara o Diamantino e o Sentinela do Serro ${ }^{72}$, ou que a opção pelo golpe parlamentar exigisse mesmo menor publicidade, o que não é incompatível com a explicação anterior e diz algo sobre as diferenças táticas dos liberais.

Em 6 de julho de 1832, O Universal trataria dos problemas do "exemplo dos Estados Unidos", opondo a ele "o estado moral de nossa civilização" frente ao "Sistema puramente democrático" e condenando "o emprego de meios violentos" e "da revolução". Defendia o ouro-pretano a "segurança das (...) Instituições e [o] aperfeiçoar o nosso Sistema", em defesa do governo regencial: "queremos um pouco mais frouxo o laço das Províncias, mas de maneira alguma desejamos ver transtornado o ligante que une as partes deste grande todo"73. É provável que já houvesse notícias das articulações pousoalegrenses ou, mesmo, que ainda se referisse aos serranos, ambos emulados pelo modelo norteamericano. Ocorre que a Sentinela do Serro o fazia com evidentes laivos de moderação, a começar pelo reconhecimento das circunstâncias, a prescrição da reforma lenta e guiada pela razão, o repúdio à violência e a afirmação da legalidade.

Qual o partido da Sentinela do Serro? É o daqueles homens prudentes, que abominam o despotismo e a anarquia; que conhecendo as circunstâncias do Brasil, mesmo para evitar maiores abalos querem lentamente e à sombra da razão fazer que o Brasil imite a Terra [de] Washington; que se procure a reforma dos costumes, para que o nosso povo seja em tudo e por tudo como o dos Estados Unidos. O nosso Norte é a Liberdade Americana, a liberdade da Pátria de Franklin, única que nos agrada; e pela qual sacrificaremos a própria vida, se preciso for. E por isso mesmo detestamos a violência, os assassinatos e as proscrições do terror: queremos que se cumpram nossos votos à sombra da legalidade ${ }^{74}$.

E Teófilo Otoni deixaria ainda mais clara a sua dissenção com os exaltados da Corte, em defesa do governo moderado e dando "nome aos bois" da república, em expressivas minúsculas, que rejeitava.

Quando a anarquia ergueu o medonho colo no Rio de Janeiro, temendo que ela triunfasse e reconhecendo que a falta de governo é o pior de todos os males que podem sobrevir ao Brasil; esquecemos as faltas dos governantes, procuramos dar-lhes força moral para se conservarem; porque antes queremos a Regência e o Ministério atual com todos os seus erros do que a república de Queiroz, Gomide, Frias, e mesmo do Sr. Barata ${ }^{75}$.

Tal quadro vai ao encontro da narrativa da famosa circular e dos extratos publicados pela imprensa

\footnotetext{
$\overline{70}$ SOUZA, Françoise Jean de Oliveira. Discursos impressos de um padre político..., Op. Cit., p. 95-97. Aproximando-se aí da proposta exaltada da Nova Luz Brasileira, conforme BASILE, Marcello. O Império em construção..., Op. Cit., p. 214.

${ }^{71}$ Pregoeiro Constitucional, n. 71, 28 de maio, e n. 72, de 4 de junho de 1831.

${ }^{72}$ Françoise Jean argumenta a necessidade de "fincar presença na Corte" de José Bento Melo. Não nos parece que isso explique o fato, até porque a atividade parlamentar de Melo, que exigia permanência na Corte, não impedira a circulação anteriormente. Cf. SOUZA, Françoise Jean de Oliveira. Discursos impressos de um padre político..., Op. Cit., p. 99-100.

${ }^{73}$ O Universal, n. 769, 6 de julho de 1832.

${ }^{74}$ O Astro de Minas, n. 644, 10 de janeiro de 1832.

${ }^{75}$ Ibidem. Os trechos mais "moderados" são descartados por ARAÚJO, Valdei; SILVA, Weder F. da. Fragmentos de um periódico perdido: o Sentinela do Serro e o sentido da 'republicanização' (1830-1832). Varia História, Belo Horizonte, vol. 27, n. 45, p. 75-95, p. 82, 2011, por CARVALHO, José Murilo de. Trajetórias republicanas. Revista do Arquivo Público Mineiro, Belo Horizonte, n. 2, ano XLIV, p. 28, julho a dezembro de 2008, e a fonte que celebrizou o fragmento, NEVES, José. Teixeira. Periódicos mineiros na Biblioteca Nacional. Anais da Biblioteca Nacional, vol. 117, p. 305, 1997.
} 
moderada da Corte ${ }^{76}$; da "democracia da gravata lavada, que com o mesmo asco repele o despotismo das turbas ou a tirania de um só"77; da exigência de virtudes e luzes, além de bons guias; e da perspectiva evolucionista da moderação que não negava e adiava sine die a utópica República ${ }^{78}$. Cabe observar que o "deitar armas" e o mobilizar povo de Otoni no Serro contra o despotismo do primeiro imperador soava mesmo como um town meeting comunal dos select-men na Nova Inglaterra, em sua frugalidade rural, e ainda sustentaria a ousadia da revolta em $1842^{79}$.

A “Constituição de Pouso Alegre", certamente elaborada e impressa antes do golpe, não continha a antes bradada monarquia federativa, unicameral, diferentemente do projeto de 1831, nem criava os intendentes municipais. Um tributo aos melindres moderados ou o reconhecimento de que as assembleias provinciais acrescidas da estipulação das atribuições dos presidentes bastavam? Mas manteve as espinhosas supressões da vitaliciedade do Senado, do Conselho de Estado e do Poder Moderador, a última, uma efetiva revolução no sistema imperial. O fim do Poder Moderador, aliás, contemplava com folgas a demanda de redução do poder pessoal do republicano Otoni.

As ações moderadas pelas reformas de 1831 e 1832 não foram mera transigência aos exaltados, ao menos não para os liberais mineiros, em especial, mas não só, do norte ou do sul. O golpe moderado, que previa o fortalecimento da Regência e a preeminência do Parlamento, na "ditadura da Câmara", como sugeriu José Murilo de Carvalho ${ }^{80}$, também não autoriza tal raciocínio in limine. No âmbito provincial, os serranos de Otoni e sua "democracia da gravata lavada" não transigiam com "o despotismo das turbas". E os proprietários de terras e escravos Custódio Dias e Ferreira de Melo não se lançaram numa aventura ao sabor dos ânimos exaltados da Corte ou do Norte, sob o risco da iminente dissolução do "edifício social". Talvez os titubeios da moderação sob o comando do Universal e de Vasconcelos, secundados pelo Astro de Caetano de Almeida, tenha sido muito tímida diante das possibilidades dos cidadãos da província populosa, econômica e socialmente sólida e sob a direção moderada.

\section{O voo curto dos dédalos}

Na Câmara vitalícia, o projeto foi separado em partes, rejeitado o artigo que indicava a apreciação da sua totalidade, e eliminados a monarquia federativa, a definição das atribuições da assembleia geral e de suas câmaras, a redução da legislatura eletiva para dois anos, a extinção da vitaliciedade do Senado e do Poder Moderador, a exigência de explicações do Executivo em caso de veto à lei aprovada pelo Parlamento, a quebra do veto pela concordância entre as duas câmaras, a extinção do Conselho de Estado e a criação do cargo de intendente para os municípios, restando a reforma dos Conselhos de províncias $^{81}$. O Universal criticaria, então, as exclusões levadas a cabo pelo Senado, inclusas a supressão da forma federativa e da preservação das prerrogativas do Poder Moderador. Não era o conteúdo formal das reformas a divergência com os exaltados ou os mineiros do "norte" e, de certa forma, o que ficou foi uma concessão ao federalismo, comemorada como necessidades mais urgentes, com a postergação das demais demandas para tempos mais propícios, contidos "os exagerados e os impacientes" e afirmada a tranquilidade na província ${ }^{82}$.

A derrota do golpe moderado, por cisões gerais e de Minas, não alterou a hegemonia na província. Não foram precisos quaisquer arroubos democráticos para que surgisse uma sedição, e a habilidade moderada fez do revés o coroamento de seu domínio. O Ato Adicional de 1834, despido de maiores radicalidades, não refugou as assembleias e o programa moderado reduziu-se ao federalismo mitigado. Tais recuos não fortaleceram o governo o suficiente. Nem as franquias de autonomia, nem a "experiência republicana" da Regência Una impediram que as revoltas persistissem e se aprofundassem.

\footnotetext{
${ }^{76}$ ARAÚJO, Valdei; SILVA, Weder F. da. Fragmentos de um periódico perdido..., Op. Cit., p. 81-93.

${ }^{77}$ OTTONI, Theophilo Benedicto. Circular dedicada aos srs. eleitores..., Op. Cit., p. 17.

${ }^{78}$ SILVA, Wlamir. Liberais e povo..., Op. Cit., p. 196-199.

${ }^{79}$ Ver ARAÚJO, Valdei; SILVA, Weder F. da. Fragmentos de um periódico perdido..., Op. Cit., p. 82 e 94, CARVALHO, José Murilo de. Trajetórias republicanas..., Op. Cit., p. 27. TOCQUEVILLE, Alexis de. A democracia na América. São Paulo: Folha de S. Paulo, 2010. p. 73-76.

${ }^{80}$ CARVAlHO, José Murilo de. Pontos e bordados: escritos de história e política. Belo Horizonte: UFMG, 1998. p. 165.

${ }^{81}$ O Universal, n. 772, 9 de julho, n. 774, 13 de julho, e n. 779, 25 de julho de 1832.

${ }^{82}$ O Universal, n. 772, 9 de julho de 1832, n. 774, 13 de julho de 1832, n. 779, 25 de julho de 1832, n. 801, 14 de setembro de 1832 , n. 808,1 de outubro de 1832 , n. 848, 4 de janeiro de 1833 e n. 835, 3 de dezembro de 1832 .
} 
Se a tranquilidade interna fez com que a moderação mineira não sustentasse nacionalmente seu projeto de forma mais radical, não a preservaria dos ares do Regresso que vinham da Corte, sob a liderança de um mineiro mutante. 


\section{A monarquia gótica versus a República do feijão com toucinho}

O horizonte da moderação mineira em 1834 era a realização de seu "protótipo de Estado", o protótipo dos Toucinheiros ${ }^{83}$, com base no Ato Adicional e na rejeição de reformas mais radicais. A partir dali e mantidas as conquistas liberais de fins do Primeiro Reinado e dos princípios da Regência, restabelecer-se-ia a ordem no país e se reforçaria a direção dos moderados, ecoando nacionalmente o seu modelo: "a eletividade local de juízes de paz, do júri e da oficialidade das guardas nacionais, as franquias provinciais, a preeminência da Câmara temporária, livre do Conselho de Estado, e um executivo forte investido na Regência Una”. Tudo temperado pela direção sem arroubos e sobressaltos e a mobilização parcimoniosa de povo.

No entanto, a multiplicação das revoltas, as erupções populares, os embaraços de um liberalismo por demais zeloso de seus monopólios e certa inabilidade do regente Feijó ${ }^{84}$ fragilizaram tal projeto, levaram à cisão moderada e, com ela, ao Regresso, num processo que não foi um mero reflexo da dinâmica do centro que teria se imposto à sociedade das províncias por uma coalizão de burocratas da Corte $^{85}$, mas, sim, uma inflexão política de envergadura. Tal inflexão, inclusive, era mais evidente nas províncias do Centro-Sul, base do Estado desde 1808, nas quais a hegemonia moderada construíra seu paradigma e enfrentaria também a sua nêmese. Inflexão que exigia um novo consenso nas províncias ${ }^{86}$, em especial em Minas, um baluarte moderado e do eixo de poder do Centro-Sul, vital à construção do consenso regressista. Far-se-ia de novo presente a imprensa periódica, no embate pedagógico pela hegemonia no espaço público mineiro.

O Astro de Minas mostraria a surpresa dos moderados mineiros. O trabalho de organização social e política que parecia terminado em 1834, com a vitória do "partido do progresso" e do qual esperavam colher os frutos do desenvolvimento da nação era baldado: "os indivíduos, os partidos, toda a nação [estavam] cansados, e aborrecidos de política", e a sociedade mostrou-se ainda em "estado de luta," e "partidos antigos ressuscitaram" num surpreendente "movimento reacionário" ${ }^{7}$. Um cansaço dos ventos liberais e uma persistência e renovação dos elementos de autoridade passados.

Pela nova configuração, entre 1835 e 1842, os periódicos dividiram-se em progressistas-liberais e regressistas-conservadores ${ }^{88}$. O eixo regressista-conservador, articulado por Bernardo Pereira de Vasconcelos, partiu de um periódico na Corte, O Sete de Abril (1833-1839), se desdobrou na criação do Paraibuna (1836-1839) em Barbacena, que trazia como epígrafe palavras do próprio Vasconcelos: "Os homens passam, passam as circunstâncias; mas os princípios subsistem, Deus louvado, a despeito das intrigas, a despeito das paixões, em todas as lutas saem triunfantes, e sabem vingar-se dos ultrajes que lhes rogam a má fé, a ambição, ou a ignorância”. A partir dali, vieram o Correio de Minas (18381844), O Unitário (1838-1840) - trazendo já no título a preocupação com a unidade do Império ante as revoltas -, e O Monarquista Leal (1840), todos de Ouro Preto. O Opinião Campanhense surgiu em 1832 como liberal-moderado e existiu até 1837, o último número em acervo é de abril de 1836. Seu redator, Bernardo Jacinto da Veiga, irmão de Evaristo da Veiga, tornou-se regressista em 1837. É possível, pois, que o periódico tenha se alinhado ao Regresso ${ }^{89}$.

No campo liberal-progressista, persistiam O Universal (1825-1842), da capital Ouro Preto - com a saída de Vasconcelos em 1836 -, com a epígrafe inspirada em J. Droz: "a ordem é banida dos lugares onde habita a tirania; a Liberdade se desterra dos países onde a desordem reina: estes dois bens deixam de existir quando os separam"90, e O Astro de Minas (1827-1839) que, já em 1835, expunha a epígrafe “(a) verdade, odiada pelos tiranos, é a única salvaguarda dos governos livres”. Surgiu em Ouro Preto O Guarda Nacional Mineiro (1838-1840) que, em 1839, ante a escalada regressista, faria em epígrafe

\footnotetext{
${ }^{83}$ SILVA, Wlamir. O protótipo dos toucinheiros: a experiência da moderação mineira. In: RESENDE, Maria Efigência Lage de; VILlALTA, Luiz Carlos. A província de Minas, vol. 2. São Paulo: Companhia do Tempo; Autêntica, 2013. p. 47-64.

${ }^{84}$ MATTOS, Ilmar Rohloff de. O tempo saquarema: a formação do Estado imperial. Rio de Janeiro: Acess, 1994. p. 149.

${ }^{85}$ CARVALHO, José Murilo de. Visconde do Uruguai. São Paulo: Ed. 34, 2002. p. 171.

${ }^{86}$ MATTOS, Ilmar Rohloff de. O tempo saquarema..., Op. Cit., p. 147-148.

${ }^{87}$ Astro de Minas, n. 1654, de 30 de agosto de 1838.

${ }^{88}$ Cf. $O$ Universal, n. 1125,3 de janeiro de 1835.

${ }^{89}$ Em seu n. 55, de 9 de maio de 1836, o Astro de Minas referia-se a uma "aliança ali iniciada entre os dois Bernardos".

${ }^{90}$ A partir de 1841, O Universal adota a discreta epígrafe em latim - in medio positas est virtus, "a virtude está no meio" - que manterá até o seu fim, em 1842. MOREIRA, Luciano da Silva. Imprensa e política..., Op. Cit., p. 197.
} 
o compromisso de resistência: "Poucos somos; mas livres, mas ousados". O Americano (1840) em São João-del-Rei guardava sutil repulsa ao peso do Antigo Regime redivivo na Europa e amainava a aversão para com a República, com uma epígrafe que citava Thomas Jefferson sobre um simbólico meridiano que separava canhões europeus e americanos, pondo-se do lado republicano do Atlântico ${ }^{91}$. O Popular (1840) de São José del-Rei resgatava no título os pendores democráticos da moderação em tempos de risco pelo princípio aristocrático, com uma epígrafe discreta de Montesquieu “(a) liberdade não consiste no poder de fazer o que se quer, mas o que as Leis permitem”, aludindo à legislação liberal. O Echo da Razão (1840-1842) de Barbacena era uma razão acuada sob ameaça de trevas, nomeando-se um eco de si mesma na lamentosa epígrafe traduzida do latim: "Todo reino dividido contra si será desolado".

A nova conjuntura envolvia temas a partir dos quais se dava a (re)construção de identidades políticas e se buscava a nova direção para a sociedade, imbricada nas relações entre as dinâmicas provincial e central: o governo Feijó ${ }^{92}$, as relações entre as assembleias geral e provincial ${ }^{93}$, a cisão

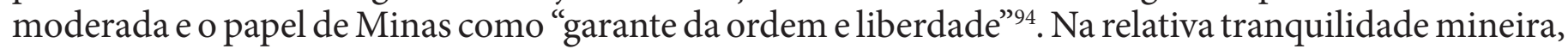
em contraste com as grandes revoltas ao Norte e ao Sul, adquiriu um papel simbólico a memória sobre a sedição de 1833, animada pela comutação de penas e a anistia para os sediciosos ${ }^{95}$, combate de forte dimensão simbólica acerca da hegemonia moderada mineira: a vitória sobre o elemento restaurador ou caramuru sem os riscos do partido exaltado ${ }^{96}$.

A cisão moderada implicaria complexas disputas. Desde a necessidade de perceber a sua dimensão e irreversibilidade até a percepção da força do Regresso, materializada na a criação do periódico Paraibuna em Barbacena, provincializando-se, sob a égide de Vasconcelos e simbolicamente com a proposta da regência de d. Januária, pondo em questão a capacidade da província como base de apoio a Feijó ${ }^{97}$. Seria ali intentado um desmonte da imagem de Bernardo Pereira de Vasconcelos, apontandose as contradições e a "versatilidade" do "pai da Seita", um "Proteu político" que se havia tornado aristocrático e retrógrado. E, para fins de exorcizar o incômodo da convivência das revoltas com o vitorioso Ato Adicional, ligava-se seu nome com uma conspiração para a elevação de d. Januária e o apelidavam “Bento Gonçalves Mineiro”. Imputava-se aos regressistas o interesse nas revoltas ${ }^{98}$.

A ascensão do Regresso em 1837 era percebida pelo Universal como uma "contrarrevolução" que ressoaria em Minas Gerais ${ }^{99}$, uma redefinição partidária e de hegemonia em curso, do Progresso ao Regresso ${ }^{100}$, isolando a moderação mineira e a pondo na defensiva em torno do Ato Adicional, das assembleias provinciais, do Código Criminal e do Júri. A pedagogia, regressista era temida e esmagadora, reconhecia-se uma "nova era no Estado (...) centralista", restando a resistência provincial, uma nova direção do bloco de proprietários e homens livres integrados socialmente, intuído pelos

\footnotetext{
${ }^{91}$ A pretexto da ocupação francesa no Amapá que se iniciara em 1835.

${ }^{92}$ O Universal, 30 de novembro de 1835 e 27 de julho de 1836; Astro de Minas, 11 de julho de 1835, 31 de maio, 27 de agosto e 13 de fevereiro de 1836. Cf. também artigo do Astro reproduzido no Universal, em 24 de julho de 1837. Apud SILVA, Wlamir. "Seguridade liberal ou sistema do medo?": dilemas da ordem na imprensa de Minas Gerais (1834-1841). In: ANTUNES, Álvaro de Araújo; SILVEIRA, Marco Antônio (org.). Dimensões do poder em Minas (séculos XVIII e XIX). Belo Horizonte: Fino Traço, 2012. p. 183.

${ }^{93}$ Astro de Minas, 14 de junho de 1836; O Universal, 29 de maio de 1837, 10 de julho de 1835, 6 de janeiro de 1836 e 1 de maio de 1837; Astro de Minas, 4 e 9 de abril de 1835, 26 de março de 1836 e 29 de maio de 1837.

${ }^{94}$ Astro de Minas, 12 de março de 1835.

${ }^{95}$ Cf. SILVA, Wlamir. Liberais e povo..., capítulo 7. Cf. O Universal e o Astro de Minas ao longo de todo o ano de 1835. Cf. especialmente a Representação (dos) povos de Ouro Preto, divulgada pelo Astro de 01/01/1835. Apud SILVA, Wlamir. "Seguridade liberal ou sistema do medo?”..., Op. Cit., p. 184.

${ }^{96}$ Astro de Minas, 7 e 26 de fevereiro de 1835; O Universal, 7 de outubro de 1836. p. 184.

${ }_{97} O$ Universal, 15 de maio e 7 de agosto de 1835; Astro de Minas, n. 1215, 5 de setembro, e n. 1225, 29 de setembro de 1835; $O$ Universal, n. 1, 1 de janeiro de 1836, n. 44, 8 de abril de 1836, 4 e 25 de abril de 1836; Astro de Minas, 12 de maio de 1836; $O$ Universal, 2 de maio de 1836, em artigo transcrito do Echo do Maranhão, e 27 de maio de 1836. Ainda sobre a proposta de d. Januária, cf. Astro de Minas, 7 e 9 de abril de 1836. O Universal, 20 de julho de 1836, ainda que criticando afirmações do periódico O Atlante da Corte. O Universal, 28 de setembro, e n. 122, 12 de outubro de 1836; Astro de Minas, 6 de fevereiro, 28 de junho, 1 e 29 de outubro de 1836. p. 184-186.

${ }^{98}$ Astro de Minas, 13 de agosto de 1836, 3 de junho e 8 de agosto de 1837, e O Parahybuna, 4 de março de 1837; Astro de Minas, 17 de setembro de 1836; O Universal, 9 de maio e 5 de outubro de 1836; Astro de Minas, 29 de março, 9 e 28 de abril, 19 e 30 de julho, 11 e 16 de agosto de 1836. Idem, p. 186.

${ }^{99}$ O Universal, 24 de maio e 14 de junho de 1837; o Astro de Minas, 24 de maio de 1837. p. 187.

${ }^{100}$ O Universal, 19 de abril de 1837.p. 187.
} 
agentes históricos, com a "difusão do princípio monárquico"101.

Na nova lógica ou sentimento em curso, a pedagogia migrou para o funcionamento cotidiano da administração e da política, numa disputa por práticas concernentes à administração e à justiça ${ }^{102}$, a substância mesma da centralização, pela multiplicação dos meios jurídico-policiais centrais ${ }^{103}$. Os progressistas-liberais temiam a exclusão da vida pública ou mesmo "o fim do governo representativo" pela rejeição de opiniões, como alarmava o redator do Astro de Minas, citando Guizot ${ }^{104}$. As recrudescidas revoltas foram o maior fermento do Regresso, e o seu diagnóstico seria central no embate político. Para o Progresso, reflexos da falta de direção política, da intolerância para com os "combates de opinião" a "preterição das fórmulas que garantem a liberdade e a segurança individual", uma "ditadura legal", assim caracterizada a centralização judiciário-policial, com as "tristíssimas consequências das desordens civis"105. Para o Regresso, frutos da liberdade excessiva dos "anarquistas" no âmbito das províncias ${ }^{106}$. Disputava-se o sentido da ordem pelas causas da desordem.

Com o ascenso do Regresso ao poder na província e o alçamento de antigos participantes da sedição a cargos recrudesceria a disputa simbólica acerca da sedição de 1833, na qual os progressistas traçavam um liame entre os "garrafistas de março" - a "hidra do despotismo metamorfoseado em regresso" - e as revoltas em curso. Os regressistas remetiam às necessidades da nação, atrelando as liberdades à conservação da ordem pública, à união das províncias e à integridade do Império. Mas $O$ Parahybuna não fugiria do quadro das identidades políticas em redefinição, opondo os monarquistas e aristocratas aos anarquistas e jacobinos, caracterizando a Regência de Feijó como um "Governo Diabo" e esgrimindo a religião com laivos de Antigo Regime. Já o Unitário opunha-se à "desmonarquização" e atribuía aos "exaltados, ou republicanos" as revoltas, e ironizava, junto com o Paraibuna, a respeito de um "Clube de anárquicos" em São João del-Rei, no qual se tramava uma "República do Feijão com Toucinho"107, além da disputa sobre o próprio Sete de Abril. O Regresso buscaria ressignificá-lo pelo reforço da autoridade monárquica, a ponto de o Astro de Minas invectivar tal apropriação simbólica: "Muita injúria se tem feito ao dia sete de abril"108.

É significativo que, em pleno Regresso, O Universal tenha recorrido a Benjamin Constant para abordar o outrora espinhoso federalismo, distando-o do "fanatismo intolerável", um "federalismo diferente”, que seria “a direção dos negócios de todos (...) por meio de seus representantes”, reiterando nada menos que a afirmação do princípio representativo. Fazia então, a guisa do centralismo, o que se poderia julgar como uma velada autocrítica moderada, quando "por estreiteza de princípios, ou por servilismo falavam sem cessar na unidade do reino, e da nação inteira", quando "o reino nada era, se alguém o concebesse abstraído das províncias; que nada era a nação inteira, separada das frações que a compõem". Mais, referia-se a um federalismo que, sem dizer o nome, se havia feito: “O Brasil adotando o sistema das localidades, por quê se declarou a sua maioria, não se retalhou, não se dividiu, não perdeu em forças". Mesmo sendo um louvor ao modelo mitigado do Ato Adicional, cuja capacidade de promover a unidade estava em xeque, reconhecia-se que a timidez reformista não impedira a desordem.

Para os moderados mineiros, o Regresso intentava "reduzir a Monarquia Brasileira a uma Monarquia absoluta e gótica, qual era antes da Independência!" e o "terror”, o "arbítrio", a "militarização, [o] despotismo [e a] perseguição" eram ineficazes contra as revoltas. Criticava-se também a clientela

\footnotetext{
$\overline{{ }^{101} \text { O Universal, } 24}$ de julho de 1837, 24 de abril, 4 e 11 de agosto de 1837; O Universal, 25 de setembro e 6 de outubro de 1837. MATTOS, Ilmar Rohloff de. O tempo saquarema..., Op. Cit., p. 148-258.

${ }^{102}$ Para Luciano Moreira, as folhas regressistas evitavam o caráter doutrinário das folhas da primeira metade das regências, evocando neutralidade. É vero, mas como um reflexo da hegemonia regressista centrada na “ordem". Cf. MOREIRA, Luciano da S. Imprensa e opinião pública..., Op. Cit., p. 216.

${ }^{103}$ Cf. também O Universal, de 5/7/1839. Apud SILVA, Wlamir. “Seguridade liberal ou sistema do medo?”..., Op. Cit., p. 189.

${ }^{104} \mathrm{O}$ Astro de Minas, 11 de setembro de 1838.

${ }^{105}$ O Universal n. 179, 1939 (sem data) e 12 de setembro de 1838.

${ }^{106}$ O Unitário, 23 de junho de 1838. p. 189.

${ }^{107}$ Cf. O Unitário, 29 de junho de 1838, 7 de agosto e 7 de dezembro de 1838; O Universal, 26 de julho de 1838 , e o Guarda Nacional Mineiro, 4 de agosto de 1838 e 17 de fevereiro de 1838; O Unitário, 23 de junho de 1838 e 31 de março de 1838 , e $O$ Parahybuna, 4 de março de 1835. p. 190.

${ }^{108}$ MOREIRA, Luciano da Silva. Imprensa e política..., Op. Cit., p. 217.
} 
e o arbítrio em nomeações, movimentações e demissões ${ }^{109}$. Na defensiva, postulavam a defesa intransigente da Constituição, na forma do Ato Adicional, contra o despotismo ministerial e a ameaça absolutista ${ }^{110}$. Recuperava-se mesmo o conceito de "federação" num amálgama entre os modelos federativo estadunidense e o da monarquia inglesa. Aventava-se até um novo Sete de Abril, resgatandose o elemento revolucionário. Criticava-se ainda, por meio do recém-criado periódico O Americano, a transação, entendida como uma indevida confusão entre o privado e o público ${ }^{111}$.

Se a opção monárquica era um lastro comum, o significado do sistema de governo era objeto de sutil disputa. O Progresso afirmava o seu monarquismo na forma da "monarquia temperada (...) por formas democráticas, que [chama] o povo por intermédio de seus representantes a tomar parte do governo do país conjuntamente com o monarca”, termos dados pelo Popular da vila de São José. Mas, em princípios de 1838, o Universal defendia-se da pecha de "panegirista da Monarquia Democrática" pelo Sete de Abril, periódico da Corte ligado a Vasconcelos, afirmando-se defensor da ordem, sem compactuar com a ditadura ${ }^{112}$. Definições que, como vimos, lembram os melindres para com o Sentinela do Serro. Já o Regresso rejeitava o epíteto de absolutistas como um "castelo imaginário" e invertia o labéu de despotismo, apondo a liberdade monárquica ao despotismo de teor republicano da oposição ${ }^{113}$.

A ameaça de exclusão pela centralização, já com a Lei de Interpretação ${ }^{114}$, conduziu o já Partido Liberal à aventura da maioridade, antes renegada como inconstitucional e um risco para a soberania ${ }^{115}$. Ato contraditório e, devido ao constrangimento dos que deviam ser mais "realistas", pontualmente vitorioso. Uma vitória de Pirro. O tomar de assalto a cidadela simbólica adversária logo soçobrou às contradições inerentes, mostrando-se uma armadilha da lógica conservadora que se mostraria com a dissolução prévia da câmara liberal eleita, uma estocada preparada pela imprensa regressista que cobria as eleições da "gente do cacete" e inflava os conflitos locais. Em meados de 1841, um correspondente habitual do Correio de Minas, cognominado de "O inimigo do Diabo", narrava as ações do "partido anarquista no Município de Tamanduá"116 relacionando os liberais aos rebeldes do Sul. Os liberais retrucavam desmentindo as violências eleitorais, das eleições com "cacetes e punhais", relatando subornos e corrupção dos regressistas. Destacavam a repressão do governo central na busca incessante de meios para o exercício do arbítrio, como a ampliação das forças armadas, os recrutamentos, a contradança de juízes e a "máquina infernal" que adviria da reforma do Código de Processo ${ }^{117}$.

Os debates do cotidiano que se multiplicaram podem causar a impressão de meras querelas pessoais ou de interesses. Mas tal disputa de práticas - insondável em termos de juízo particular envolvia concepções políticas. Assim, um deputado provincial conservador marcava sua diferença para com os "monarquistas de praça pública" ${ }^{118}$. E o Correio de Minas, as diferentes épocas da nação e que o elemento político ou revolucionário havia mudado da liberdade para a reflexão e, então, predominavam a religião, a indústria, a ciência e os costumes, sendo os regressistas defensores do "espírito da nossa idade"119. Enquanto isso, o Universal afirmava que os homens nascidos na América "devem o seu estado de civilização à liberdade" e criticava o "atropelo das formas que garantem a

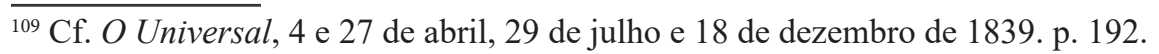

${ }^{110}$ Cf. O Universal, 16 de agosto de 1837 e 12 de janeiro de 1838, e o Guarda Nacional Mineiro, 10 de março e 28 de setembro de 1838, p. 192; e ainda O Universal, 29 e agosto e 8 de outubro de 1838, e 21 e 26 de julho e 5 de agosto de 1839; e o Guarda Nacional Mineiro, 30 de outubro de 1838. p. 193.

${ }^{111}$ Cf. o Guarda Nacional Mineiro, 10 de agosto e 4 de outubro de 1838. p. 193, O Universal, 12 e 15 de janeiro de $1838, O$ Universal, 5 de janeiro de 1838, O Americano, 3, 9, 15 e 25 de abril e 2 de maio de 1840. p. 193. Cf. o Astro de Minas, 21 de agosto de 1838 , replicando um artigo do Guarda Nacional Mineiro.

${ }_{112}$ O Popular, 2 de janeiro de 1840, O Universal, 1 de janeiro de 1838, 17 de julho de 1839 e 3 de dezembro de 1839. p. 193.

${ }^{113}$ O Correio de Minas, 6 e 20 de novembro de 1841. p. 195.

${ }^{114}$ O Universal, 21, 26 e 29 de julho de 1839, e 1 de julho de 1840, e o Astro de Minas, 7 e 9 de 1839. p. 194.

${ }^{115}$ Contra os regressistas, Sete de Abril e Parahybuna, cf. O Universal, 2 e 30 de junho de 1837. p. 194.

${ }^{116}$ O Correio de Minas, 1 de juho de 1841. p. 194.

${ }^{117}$ O Universal, 28 de agosto de 1839 e 1 de março, 5 de maio, 8 de dezembro, 25 de outubro, 22 de março, 1 de dezembro e 15 de janeiro de 1841.p. 195.

${ }^{118}$ O Correio de Minas, 16 de março de 1841. p. 195.

${ }^{119}$ O Correio de Minas, 7 e 14 de agosto de 1841. p. 196.
} 
liberdade da tribuna"120. Tudo isso era um confronto de projetos e de culturas políticas na concreção provincial e local, uma pedagogia da ordem e uma combalida utopia. Em fins de 1841, com a aprovação da reforma do Código de Processo e a prevista dissolução prévia da câmara eleita, a imprensa liberal dava mostras de desânimo. Configurava-se cada vez mais o predomínio da "seita das transações"121 dada pela dinâmica do centro. As ruínas do projeto liberal ainda permitiriam a defensiva revolta de 1842 que viria a ser o canto do cisne dos Toucinheiros.

O protótipo de Estado liberal-moderado mineiro dava sinais de esgotamento diante do que se chamou de um "protótipo das necessidades públicas"122 de uma ordem que se impunha como resposta natural aos conflitos. Uma naturalidade construída pela difusão de conceitos entrelaçados às práticas políticas provinciais, no seio de uma nova conjuntura em que as novas formas jurídicas ganharam um sentido. A pujante herança moderada e a onda regressista realizaram um embate que desnuda o avanço regressista, ao menos no Centro-Sul, e a persistência liberal mineira.

\section{O nevoeiro espesso: o liberalismo claudicante}

Em um opúsculo acerca do surgimento da imprensa no Brasil do século XIX, Marco Morel e Mariana Monteiro de Barros dizem que, então, “imprensa e nação brasileira são praticamente simultâneas”. Mais que sugestiva tal observação é uma singela, mas poderosa, chave heurística sobre a gênese da nação no país, e da imprensa como fonte e objeto - polissemia também percebida pelos autores - daquele processo $^{123}$, no qual se encontravam as potencialidades e amarras da participação política popular. Uma viagem que não diferia em absoluto das realizadas em outras partes do mundo e que dependeu de condições peculiares, é certo, mas também de escolhas e trajetórias não inexoráveis ${ }^{124}$ e, ainda, sob o signo universal da distinção nos sistemas representativos, de um efeito aristocrático ${ }^{125}$ pelo qual a medida do povo-cidadão, em perfil e forma, não é, nem de longe, uma deformação brasileira.

A pedagogia da imprensa mineira, em especial a liberal, pode ser estudada pelas suas escolhas frente ao horizonte de possibilidades e, assim, contribuir para aproximações dos seus resultados, provincial e nacionalmente, pela incessante circulação e debate historiográfico. Afinal, a tríade exaltados, moderados e caramurus é pertinente, guardadas as diferenças espaciais e sua maleabilidade designativa. Minas tinha lá suas maleabilidades no cenário imperial, quanto a suas bases materiais e sociais e trajetórias políticas. A partir delas, uma miríade de personagens fez escolhas, teve dúvidas e angústias. A investigação de suas ações remete, claro, aos constrangimentos econômicos, sociais e outros, mas também a suas escolhas e seus desdobramentos.

Seria pretensioso julgar as ações dos periodistas mineiros e as repercussões de seus escritos e pedagogia. Já o seria no âmbito provincial, o é ainda mais no conjunto do Império. O que chamamos de Protótipo dos Toucinheiros, invertendo um estigma pespegado por um adversário político, projeto produzido por uma elite situada na interiorana e frugal economia de abastecimento, era apenas uma peça do mosaico ${ }^{126}$. Esta modesta investigação aponta para dois elementos reflexivos: 1) as dimensões continentais não possibilitariam a relação entre as peças do mosaico?; 2) a mobilização reformista não deixaria, de todo modo, um ganho no sentido da representação? A partir delas: os moderados

\footnotetext{
$\overline{{ }^{120} \text { O Universal, } 1}$ de novembro de 1841. p. 196.

${ }^{121}$ O Universal, 13 de setembro e 16 de julho de 1841. p. 196.

${ }^{122}$ O Universal, 2 de junho de 1841. p. 196.

${ }^{123}$ MOREL, Marco; BARROS, Mariana M. de. Palavra imagem e poder: o surgimento da imprensa no Brasil do século XIX. Rio de Janeiro: DP\&A, 2003. p. 7-8.

${ }^{124}$ JANCSÓ, István. A construção dos Estados nacionais na América Latina: apontamentos para o estudo do Império como projeto. In: SZMRECSÁNYI, T.; LAPA, J. R. do A. (org.). História econômica da Independência e do Império. São Paulo: Hucitec, 1996. p. 3 .

${ }^{125}$ MANIN, Bernard. Los princípios del gobierno representativo..., Op. Cit., em contraponto com leituras etéreas das relações entre dirigentes e dirigidos nas sociedades modernas, num pêndulo extremo entre elites e multidão que desqualifica mediações representativas. A propósito ver AGUIAR, Thaís Florêncio de. Demofobia e demofilia: dilemas da democratização. Rio de Janeiro: Azougue, 2015.

${ }^{126}$ JANCSÓ, István; PIMENTA, João Paulo G. Peças de um mosaico (apontamentos para o estudo da emergência da identidade nacional brasileira). In: MOTA, Carlos Guilherme (org.). Viagem incompleta - a experiência brasileira 1500-2000. Formação histórias. São Paulo: Senac, 2000. p. 127-76. Para as relações entre a economia e sociedade de abastecimento de Minas e a vida política ver SILVA, Wlamir. Liberais e povo..., op. cit, em especial os capítulos 1 e 3.
} 
mineiros não teriam sido tímidos em fortalecer sua experiência política, independente da possível derrota ao nível nacional, e liderar um projeto que não fosse sugado pelo conservadorismo? Enfim, tal a experiência representativa, como outras, não poderia legar elementos democráticos no alvorecer do nosso Estado-Nação?

\section{Referências bibliográficas}

AGUIAR, Thaís F. de. Demofobia e demofilia: dilemas da democratização. Rio de Janeiro: Azougue, 2015.

[O] Americano. São João del-Rei, 1840.

ANDRADE, Marcos F. de. Família e política nas regências: possibilidades interpretativas das cartas pessoais de Evaristo da Veiga (1836-1837). In: RIBEIRO, Gladys Sabina; FERREIRA, Tania M. T. B. C. (org.). Linguagens e práticas de cidadania no século XIX. São Paulo: Alameda, 2010.

ARAÚJO, Valdei; SILVA, Weder F. da. Fragmentos de um periódico perdido: o Sentinela do Serro e o sentido da 'republicanização' (1830-1832). Varia História, Belo Horizonte, vol. 27, n. 45, p. 75-95, 2011.

Astro de Minas. São João del-Rei, 1827-1839.

Aurora Fluminense. Rio de Janeiro, n. 269, 23 de novembro de 1829.

BASILE, Marcello. O Império em construção: projetos de Brasil e ação política na Corte imperial. 2004. 490 f. Tese (Doutorado em História Social), Instituto de Filosofia e Ciências Sociais, Universidade Federal do Rio de Janeiro, Rio de Janeiro, 2004.

. O laboratório da nação: a era regencial (1831-1840). In: GRINBERG, Keila \& SALLES, Ricardo (org.). O Brasil imperial, vol. II: 1831-1870. Rio de Janeiro: Civilização Brasileira, 2009.

O "negócio mais melindroso": reforma constitucional e composições políticas no Parlamento regencial (1831-1834). In: NEVES, Lúcia Maria Bastos P. das (org.). Livros e impressos: retratos dos Setecentos e dos Oitocentos. Rio de Janeiro: Eduerj, 2009.

BEAUZÉ, Nicolas. Língua (Gramática). In: DIDEROT, Denis; D’ALEMBERT, Jean Le Rond. Enciclopédia, ou Dicionário razoado das ciências, das artes e dos ofícios, vol. 2: O sistema dos conhecimentos. São Paulo: Editora Unesp, 2015.

BRASILIENSE, Américo. Os programas dos partidos e o Segundo Império. Brasília: Senado Federal; Rio de Janeiro: Fundação Casa de Rui Barbosa, 1979.

CARVALHO, José Murilo de. Federalismo y centralización en el Império brasileño: história e argumento. In: CARMAGNANI, Marcello (coord.). Federalismos latinoamericanos: México/Brasil/Argentina. México: Fondo de Cultura Económica, 1993.

. Trajetórias republicanas. Revista do Arquivo Público Mineiro, Belo Horizonte, ano XLIV, n. 2, p. 28, julho a dezembro de 2008.

. Visconde do Uruguai. São Paulo: Ed. 34, 2002.

Pontos e bordados: escritos de história e política. Belo Horizonte: UFMG, 1998.

CARVALHO, José Murilo de; BASTOS, Lúcia; BASILE, Marcello (org.). Guerra literária: panfletos da Independência (1820-1823), vol. 2. Belo Horizonte: UFMG, [1821] 2014.

Constitucional Mineiro. São João del-Rei, 1832-1833.

[O] Correio de Minas. Ouro Preto, 1841-1842.

COSER, Ivo. O conceito de federalismo e a ideia de interesse no Brasil do século XIX. Dados - Revista de Ciências Sociais, Rio de Janeiro, vol. 51, n. 4, p. 941-981, 2008.

O pensamento político dos liberais: o conceito de americanismo na construção do Estado brasileiro. Perspectivas: Revista de Ciências Sociais, São Paulo, Unesp, vol. 38, p. 49-73, 2010. Disponível em: <http://seer.fclar.unesp.br >. Acesso em: 15 de março de 2018.

COSPITO, Giuseppe. Representados-representantes. In: LIGUORI, Guido; VOZA, Pasquale (org.). Dicionário gramsciano (1926-1937). São Paulo: Boitempo, 2017.

CURIEL, Carole. De los muchos, uno: el federalismo en el espacio ibero-americano; THIBAUD, Clément. Federalismo - Colômbia; ÁVILA, Alfredo. Federalismo - Colômbia. In: SEBASTIÁN, Javier Fernández (dir.). Diccionario político y social del mundo ibero-americano. La era de las revoluciones, 1750-1850 [Iberconceptos-I]. Madri: Fundación Carolina; Sociedad Estatal de Conmemoraciones Culturales; Centro de Estudios Políticos y Constitucionales, 2009. 
Dicionário histórico-biográfico das ciências da saúde no Brasil (1832-1930). Disponivel em: < http://www. dichistoriasaude.coc.fiocruz.br/iah/pt/verbetes/reisjarope.htm\#dados>. Acesso em: 15 mar. 2018.

DOLHNIKOFF, Miriam. Império e governo representativo: uma releitura. Caderno CRH, Salvador, vol. $21, \mathrm{n}$. 52, p. 13-23, jan./abr. 2008.

DOLHNIKOFF, Miriam et al. Representação política no Império: crítica à ideia do falseamento institucional. In: LAVALLE, Adrian G. (org.). O horizonte da política. São Paulo: Editora Unesp; CEM, 2012.

Estrela Marianense. Mariana, 1830-1832.

GRAMSCI, Antônio. Cadernos do cárcere. Seis volumes. Rio de Janeiro: Civilização Brasileira, 1999-2002.

Guarda Nacional Mineiro. Ouro Preto, 1838-1840.

GUERRA, François-Xavier. El soberano y su reino: reflexiones sobre la génesis del ciudadano en América Latina. In: SABATO, Hilda. (coord.). Ciudadanía política y formación de las naciones: perspectivas históricas de América Latina. México, D.F.: Fondo de Cultura Económica, 1999.

GUIMARÃES, Lúcia Maria P. et al. Republicanos ou federalistas. In: ENCONTRO REGIONAL DA ANPUHRJ, 1990, Rio de Janeiro. História hoje: balanço e perspectivas. Anais do IV Encontro Regional da ANPUH-RJ. Rio de Janeiro, 1990.

JANCSÓ, István; PIMENTA, João Paulo G. Peças de um mosaico (apontamentos para o estudo). In: MOTA, Carlos Guilherme (org.). Viagem incompleta. A experiência brasileira (1500-2000). Formação - histórias. São Paulo: Senac, 2000.

JANCSÓ, István. A construção dos Estados nacionais na América Latina: apontamentos para o estudo do Império como projeto. In: SZMRECSÁNYI, T.; LAPA, J. R. do A. (org.). História econômica da Independência e do Império. São Paulo: Hucitec, 1996.

LAMOUNIER, Bolívar. Da Independência a Lula: dois séculos de política brasileira. São Paulo: Augurium, 2005.

LOSURDO, Domenico. Contra-história do liberalismo. Aparecida: Ideias \& Letras, 2006.

LYRA, Maria de Lourdes V. Centralisation, systeme fiscal et autonomie provinciale dans l'Empire brésilien: la province da Pernambuco - 1808-1835. Paris: Universidade de Paris X, 1985.

MANIN, Bernard. Los princípios del gobierno representativo. Madri: Alianza Editorial, 2006.

MARIANO, Delsa de F. dos S. Escravos e libertos: autores de ações de liberdade em Diamantina (1850-1851). 119 f. Dissertação (Mestrado profissional interdisciplinar em Ciências Humanas), Universidade Federal dos Vales do Jequitinhonha e Mucuri, Diamantina, 2015.

MARX, Karl. Crítica da filosofia do direito de Hegel. São Paulo: Boitempo, 2010.

MATTOS, Ilmar R. de. O tempo saquarema: a formação do Estado imperial. Rio de Janeiro: Acess, 1994.

MELO, Geraldo P. de. Traços biographicos de serranos ilustres, já falecidos. Revista do Arquivo Público Mineiro, Belo Horizonte, vol. 1, 1905.

MOREIRA, Luciano da Silva. Imprensa e política: espaço público e cultura política na província de Minas Gerais, 1828-1842. 272 f. Dissertação (Mestrado em História), UFMG, Belo Horizonte, 2006.

Imprensa e opinião pública no Brasil Império: Minas Gerais e São Paulo (1826-1842). 300 f. Tese (Doutorado em História), Faculdade de Filosofia e Ciências Humanas, Universidade Federal de Minas Gerais, Belo Horizonte, 2011.

Leituras na província: impressos e práticas de leitura na província de Minas Gerais (18281842). In: SIMPÓSIO NACIONAL DA ASSOCIAÇÃO DOS PROFESSORES DE HISTÓRIA, 2007, Florianópolis. Anais do XXIV Simpósio Nacional da Ássociação dos Professores Universitários de História. São Paulo: ANPUH, 2007, p. 3. Disponível em: <http://anais.anpuh.org/wp-content/uploads/mp/pdf/ ANPUH.S24.0944.pdf>. Acesso em: 15 mar. 2018.

MOREL, Marco; BARROS, Mariana Monteiro de. Palavra imagem e poder: o surgimento da imprensa no Brasil do século XIX. Rio de Janeiro: DP\&A, 2003.

As transformações dos espaços públicos: imprensa, atores políticos e sociabilidades na cidade imperial (1820-1840). São Paulo: Hucitec, 2005.

NASCIMENTO, Alexsandro R. A justiça quase perfeita: discussões sobre os juízes municipais na comarca do Recife. In: SIMPÓSIO NACIONAL DE HISTÓRIA, 2013, Natal. Anais do XVII Simpósio Nacional de História. Natal, 2013.

NEVES, José. T. Periódicos mineiros na Biblioteca Nacional. Anais da Biblioteca Nacional, vol. 117, p. 305, 
1997.

[O] Novo Argos. Ouro Preto, 1829-1834.

O Tareco Militar. Ouro Preto, 1833.

O Unitário. Ouro Preto, 1838-1840.

OLIVEIRA, Carlos Eduardo França de. Construtores do Império, defensores da província: São Paulo e Minas Gerais na formação do Estado nacional e dos poderes locais. Tese (Doutorado em História), Departamento de História, Faculdade de Filosofia, Letras e Ciências Humanas, Universidade de São Paulo, São Paulo, 2014.

OLIVEIRA, Françoise Jean de. Discursos impressos de um padre político: análise da breve trajetória d'O Pregoeiro Constitucional. Almanack Braziliense, n. 5, maio 2007. Disponível em: <https://www.revistas. usp.br/alb/article/view/11660/13430>.

Opinião Campanhense. Campanha, 1832-1836.

OTTONI, Theophilo Benedicto. Circular dedicada aos srs. eleitores de senadores pela província de Minas Geraes. Rio de Janeiro: Typ. do Correio Mercantil, 1860.

[O] Parahybuna. Barbacena, 1837-1838.

PAULA, Alexandre M. de. O Regresso em Minas Gerais: "déspotas e republicanos" na imprensa mineira (18371840). 170 f. Dissertação (Mestrado em História), Universidade Federal de São João del-Rei, São João del-Rei, 2013.

PEREIRA, Luísa R. O povo na história do Brasil: linguagem e historicidade no debate político (1750-1870). São Paulo: Paco, 2016.

[O] Popular. São José do Rio das Mortes, 1840.

Pregoeiro Constitucional. Arraial de Pouso Alegre, 1831.

REZENDE, Francisco de Paula Ferreira de. Minhas recordações, 1832-1893. Belo Horizonte: Imprensa Oficial, 1987.

ROSANVALLON, Pierre. La consagración del ciudadano. Historia del sufragio universal. México: Instituto Mora, 1999.

SANTOS, Marileide L. dos. Educação, assistência e sociabilidade: o governo dos pobres em Sabará/MG (18321860). 200 f. Dissertação (Mestrado em Educação), Faculdade de Educação, Universidade Federal de Minas Gerais, Belo Horizonte, 2007.

SELINGARD, Cristóvão. Educação religiosa, disciplina e poder na terra do ouro: a história do Seminário de Mariana, entre 1750 e 1850. 222 p. Dissertação (Mestrado em Educação), Universidade Federal de São Carlos, São Carlos, 2007.

SIERRA, María; PEÑA, Maria Antonia; ZURITA, Rafael. Elegidos y elegibles: la representación parlamentaria en la cultura del liberalismo. Madri: Marcial Pons, 2010.

SILVA, Wlamir. Princípios substanciais, circunstâncias acidentais: da gênese do liberalismo moderado na imprensa mineira do Primeiro Reinado (1825-1831). In: FONSECA, Silvia Carla P. de B.; CORREA, Maria Letícia (org.). 200 anos de imprensa no Brasil. Rio de Janeiro: Contra Capa, 2008.

. A imprensa e a pedagogia liberal na província de Minas Gerais (1825-1842). In: FERREIRA, Tânia. Maria B. da C.; MOREL, Marco; NEVES, Lúcia Maria B. P. (org.). História e imprensa: representações culturais e práticas de poder. Rio de Janeiro: DP\&A/ Faperj, 2006.

Entre un diestro nauta y ciertos espíritus traviesos: la independencia en la provincia de Minas Gerais (1821-1824). Nuevo Mundo Mundos Nuevos, n. 13, 2013. Disponível em: < http://journals. openedition.org/nuevomundo/65297>. Acesso em: 10 mar. 2018.

Liberais e povo: a construção da hegemonia liberal-moderada na província de Minas Gerais (1830-1834). São Paulo: Hucitec, 2009.

O protótipo dos toucinheiros: a experiência da moderação mineira. In: RESENDE, Maria Efigência Lage de; VILLALTA, Luiz Carlos. A província de Minas, vol. 2. São Paulo: Companhia do Tempo; Autêntica, 2013.

SLEMIAN, Andréa. Sob o império das leis. Constituição e unidade nacional na formação do Brasil (18221834). São Paulo: Hucitec / Fapesp, 2009.

TOCQUEVILLE. Alexis de. A democracia na América. São Paulo: Folha de S. Paulo, 2010.

O Universal. Ouro Preto, 1825-1842. 
VEIGA, José Pedro X. da. Ephemerides mineiras (1664-1897). Belo Horizonte: Centro de Estudos Históricos Culturais/ Fundação João Pinheiro, 1998.

Recebido em: 28/04/2018 - Aprovado em: 21/09/2018 